GEOLOGICAL SURVEY CIRCULAR 730

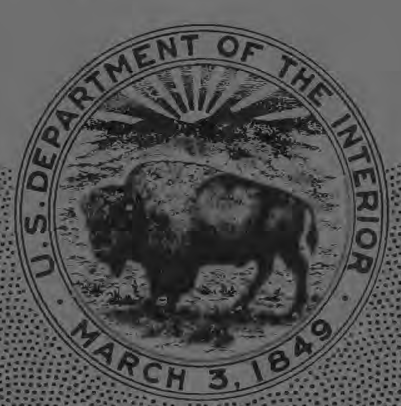

\title{
Geologic Appraisal of the
}

Petroleum Potential of

Offshore Southern

California: The

Borderland Compared to

Onshore Coastal Basins 
Geologic Appraisal of the

Petroleum Potential of

Offshore Southern

California: The

Borderland Compared to

Onshore Coastal Basins

By James C. Taylor

GEOLOGICAL SURVEY CIRCULAR 730 


\section{United States Department of the Interior}

THOMAS S. KLEPPE, Secretary

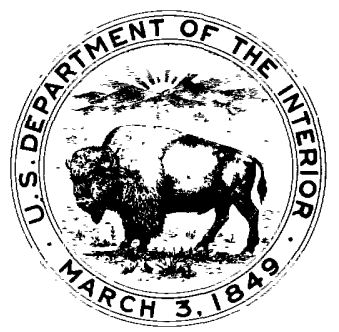

\section{Geological Survey}

V. E. McKelvey, Director

\section{Library of Congress Cataloging in Publication Data}

Taylor, James Carlton, 1924-

Geological appraisal of the petroleum potential of offshore southern California.

(Geological Survey circular ; 730)

Includes bibliographical references.

1. Petroleum in submerged lands-California, Southern. 2. Petroleum-Geology-California, Southern. 3. Gas, Natural, in submerged lands-California, Southern. 4. Gas Natural-Geology-California, Southern. I. Title. II. Series: United States. Geological Survey. Circular ; 730.

QE75.C5 no. 730 [TN872.C2] 553'.28'097949 76-608074 


\section{CONTENTS}

\begin{abstract}
Introduction

Acknowledgments

Geologic setting of the southern Californ

Oil and gas in onshore California basins

Oil and gas in California coastal basins

Distribution of petroleum in coastal basins

Field size

Age

Reservoir rock type

Oil and gas geology-southern California borderland

Oil and gas seeps

Offshore wells
\end{abstract}

\begin{tabular}{|c|c|c|}
\hline Page & & Page \\
\hline 1 & Oil and gas geology-southern California & \\
\hline 2 & borderland-Continued & \\
\hline 2 & Sediment thicknesses & 15 \\
\hline 2 & Potential petroleum source rocks & 19 \\
\hline 4 & Organic maturity & 21 \\
\hline 5 & Organic maturity of Paleogene and & \\
\hline 5 & Neogene samples & 24 \\
\hline 5 & Potential petroleum reservoir rocks & 26 \\
\hline 10 & Paleogene age & 26 \\
\hline 11 & Neogene age & 26 \\
\hline & Potential petroleum traps & 28 \\
\hline 12 & Petroleum resource estinates & 30 \\
\hline 13 & Conclusions & 32 \\
\hline 15 & References cited & 33 \\
\hline
\end{tabular}

\section{ILLUSTRATIONS}

Figure 1. Index map of continental borderland of southern California showing inner and outer basin areas _.

2. Cumulative production and estimated recovery of oil and gas from known fields in onshore and offshore basins of California

3. Histogram of cumulative production by age and basin for basins west of the San Andreas fault

4. Size distribution of fields larger than 20 million barrels in basins west of San Andreas fault

5. Areas of the borderland under less than $200 \mathrm{~m}$ water

6. Core holes and stratigraphic tests drilled on the borderland prior to the Supreme Court's ruling in January 1966 on the State-Federal boundary

7. Organic carbon content (weight percent) of dart outcrop samples of Eocene and Oligocene age and inferred limits of Paleogene sediments

8. Organic carbon content (weight percent) of Miocene dart cores

9. Organic carbon content (weight percent) in Holocene sediments from basin floors, outer slopes, and ocean floor

10. Source rock analysis chart with organic carbon content plotted against hydrocarbon for Eocene-Oligocene and Miocene samples

11. Original and interpreted northeast-southwest seismic profile across Tanner Bank, showing paleontologically dated samples

\section{TABLES}

TABLE 1. 59 largest fields in coastal basins west of San Andreas fault

2. Distribution of petroleum by stratigraphic age for coastal basins west of the San Andreas fault 
3. Summary of organic chemistry on dart samples by stratigraphic age, southem California borderland

4. Estimated undiscovered recoverable resources, southern California borderland

5. Major fields: Los Angeles basin

6. Major fields: Ventura basin

7. Major fields: Santa Maria basin

8. Major fields: Cuyama basin

10. Organic geochemistry of dart samples from the southern California borderland and Miocene outcrop samples from the southwestern Santa Ynez Mountains

11. Organic geochemistry of Eocene outcrop samples, San Nicolas Island

\section{DEFINITIONS}

Reserve terminology varies between agencies. Data on reserves of oil and gas have been obtained from the American Petroleum Institute (API) and their terms (API, 1975, p. 14-17) in italies are compared to those of the U.S. Department of Interior (Miller and others, 1975, p. 8-9).

Measured (proved) reserves of crude oil "are the estimated quantities of all liquids statistically defined as crude oil, which geological and engineering data demonstrate with reasonable certainty to be recoverable in future years from known reservoirs under existing economic and operating conditions" (API, 1975, p. 17).

Indicated (indicated additional) reserves are those "additional recoveries in known reservoirs (in excess of proved reserves) which engineering knowledge and judgment indicate will be economically available by application of fluid injection (or other improved recovery techniques), whether or not such program is currently installed" API, 1975, p. 14, 22).

Ultimate recovery represents the "sum of cumulative production to date plus the current estimate of proved reserves" (API, 1975, p. 17). This term is not used by U.S. Department of Interior.

Demonstrated reserves are "the sum of measured and indicated reserves" (Miller and others, 1975, p. 9).

Inferred reserves are "reserves in addition to demonstrated reserves eventually to be added to known fields through extensions, revisions, and new pays" (Miller and others. 1975, p. 9). The API has no equivalent term.

Resources are the "concentrations of naturally occurring solid, liquid. or gaseous materials in or on the Earth's crust in such form that economic extractions of a commodity is currently or potentially feasible" (Miller and others, 1975, p. 8).

Undiscovered resources (undiscovered reserves) are "quantities of a resource estimated to exist outside of known fields on the basis of broad geologic knowledge and theory" (Miller and others, 1975, p. 8).

Identified resources are the "specific accumulations of economic resources whose location, quality, and quantity are estimated from geologic evidence supported in part by engineering measurements" (Miller and others, 1975, p. 8). 


\title{
Geologic Appraisal of the Petroleum Potential of Offshore Southern California: The Borderland Compared to Onshore Coastal Basins
}

\author{
By James C. Taylor
}

\section{ABSTRACT}

Offshore southern California is part of a much larger Pacific continental margin, and the two areas have a similar geologic history at least as far back as middle Tertiary time. Assessment of the petroleum potential of the offshore Southern California borderland is accomplished by examining the adjacent highly explored productive coastal basins in the tectonically unstable area west of the San Andreas fault. Known oil and gas accumulations in this region can be characterized as follows: 88 percent comes from the Los Angeles and Ventura basins; 87 percent has been found in late Miocene and younger strata and only 0.2 percent has been found in Eocene strata; 80 percent has been found in thick deposits of deep-water turbidite reservoirs; and 5 percent has been found in fractured Miocene siliceous shale reservoirs. The percentage of siliceous shale reservoirs will increase as a result of recent discoveries in this rock type in the Santa Barbara Channel. Of the 212 known fields only 5 are giants (greater than 500 million barrels), and these fields account for 52 percent of all past production from the region. Most fields are faulted anticlines, and the largest fields have the highest oil recoveries per acre.

Geologic knowledge of the off shore is limited by the availability of data. Data have been obtained from geophysical surveys, analyses of bedrock samples from the sea floor, and extrapolations of data from the mainland and offshore islands. Several factors have a negative effect on the assessment of the petroleum potential of the southern California borderland. They are:

1. The Neogene section is relatively thin, and the Paleogene section is thin and has a limited distribution.

2. Over large areas, Miocene sediments apparently rest directly on basement.

3. Along much of the Santa Rosa-Cortes Ridge, sediments are uplifted and truncated, exposing Paleogene rocks.

4. Organic content in Paleogene sediments is believed too low to generate large amounts of petroleum.

5. Source rocks are immature, even in sediments as old as Eocene.
6. Burial and thermal history are insufficient for the generaton of hydrocarbons over much of the borderland area.

7. Documented oil and gas seeps are unknown seaward of the Channel Islands.

8. Limited exploratory drilling nearshore, the best prospective area, has not been favorable.

9. Adequate or thick reservoirs of deep-water turbidite origin are not evident.

These negative factors are partly offset by the following positive factors:

1. Miocene sediments are excellent potential source rocks.

2. Asphaltic oil in rocks of Monterey-type lithology may be generated at lower than normal temperatures.

3. Shallow-water sands of reservoir quality possibly are present in the uppermost Paleogene and lowermost Neogene section.

4. Potential structural traps may be analogous to major structural producing trends onshore.

5. Fractured shale reservoirs may be present along flanks of major banks and ridges.

6. Buried and unsampled Paleogene and Late Cretaceous sediments may be better source rocks than those sampled and measured.

The southern California borderland, although a part of a locally rich petroliferous region, has no known basins with geologic histories or characteristics similar to the Los Angeles and Ventura basins. Some offshore basins are similar to less endowed basins in terms of petroleum potential such as the Santa Maria and Salinas basins. Areas with the best petroleum potential may be in deep water (greater than $500 \mathrm{~m}$ ). Some of the past high estimates of the petroleum potential may have been overstated; the existing geologic data tend to substantiate low estimates of 0.6 to 5.8 billion barrels of oil and 0.6 to 5.8 trillion $\mathrm{ft}^{3}$ of gas for the southern California borderland at the 5 and 95 percent probability level. 


\section{INTRODUCTION}

Public concern about the availability of adequate energy resources has led to reevaluations of the remaining petroleum reserves and the potential but as yet undiscovered petroleum resources of the United States (Miller and others, 1975). The continental shelves are believed to hold large quantities of undiscovered oil and gas resources. After executive action in January 1974 calling for the increased exploration of the Federal outer continental shelf areas, the southern California borderland was nominated as the first of these frontier areas to be leased. The area lies adjacent to the Los Angeles basin, one of the richest oil basins in the world, and is immediately south of the productive Ventura basin. Also in the region numerous offshore fields had been discovered in the 3-mile offshore zone of California State waters. The first offshore development was in 1896 when wells were drilled from wooden piers in the Summerland field. Additional discoveries in State waters occurred after the first California tideland leasing act in 1921 and continued as other similar acts were passed in 1938, 1955, and 1957 (Frame, 1960 , p. 6-9). Several additional discoveries have been made after Federal leasing in February 1968 in the Santa Barbara Channel, an offshore extension of the Ventura basin (Wilson, 1975).

This is one of several U.S. Geological Survey reports based on continuing study of the geology of the borderland (Vedder, Wagner, and Schoellhamer, 1969; Vedder and others, 1974, 1976; Campbell and others, 1975; Sasnett and others, unpub. data; Junger and Wagner, unpub. data ; Howell, 1975 ; Roberts, 1975 ; Greene and others, 1975; Greene, Silver, and von Huene, 1975; Wolf, 1975; Wagner, 1975 ; Vedder, 1975 ; Moore and Beyer, 1975; Moore and McCulloch, 1975). This report is a synthesis of geologic knowledge as it pertains to an appraisal of the petroleum potential of this area. The area to be evaluated (fig. 1) is approximately equal to that studied by Vedder and others (1974) and includes that part of the borderland that lies seaward from the shoreline to the base of the continental slope and between $34^{\circ} \mathrm{N}$ latitude west of Mugu Canyon and $32^{\circ} \mathrm{N}$ latitude west of the U.S.-Mexico boundary. This area covers more than $21,600 \mathrm{mi}^{2}$ and has been di- vided into an inner basin and an outer basin area.

\section{ACKNOWLEDGMENTS}

Special appreciation is expressed to George Claypool for his expertise and services on the organic chemical analyses, to R. E. Arnal and J. D. Bukry for paleontological determinations, to R. M. Egbert and M. L. Randall for assistance in the statistical tabulations of production. I am especially grateful to J. G. Vedder and E. W. Scott for contributing their knowledge of the area, and to B. M. Miller and G. L. Dolton of the USGS Resource Appraisal Group and to R. F. Mast, for their interest and many helpful suggestions.

\section{GEOLOGIC SETTING OF THE SOUTHERN CALIFORNIA REGION}

The borderland has been referred to as the offshore continuation of the California mainland (Emery, 1960; Parker, 1971). Consequently, this study of its petroleum potential draws heavily on comparisons of the borderland with presumed analogous onshore basins where the petroleum exploration has been intense, the geology is much better known, the factors governing accumulations of oil and gas are generally agreed upon, and probably all of the giant oil fields (greater than 500 million barrels) have already been discovered. A synopsis of the distribution and characteristics of major accumulations onshore and the factors controlling their occurrence is a natural starting point for assessing the offshore potential.

Classification of basins by tectonic setting has been recently reviewed by Halbouty (Halbouty and others, 1970). The productive basins in California all occur on intermediate-type crust at the borders of present or former continental plates, and the San Andreas fault separates the Sacramento and San Joaquin basins of the Great Valley from the coastal basins to the west (fig. 2). The Tertiary tectonic history of these two areas is sufficiently different to justify excluding the Great Valley as a valid analog to the borderland. Major deformation occurred mainly on the west side of the San Joaquin Valley where wrenching along the San Andreas fault produced oblique and en enchelon 


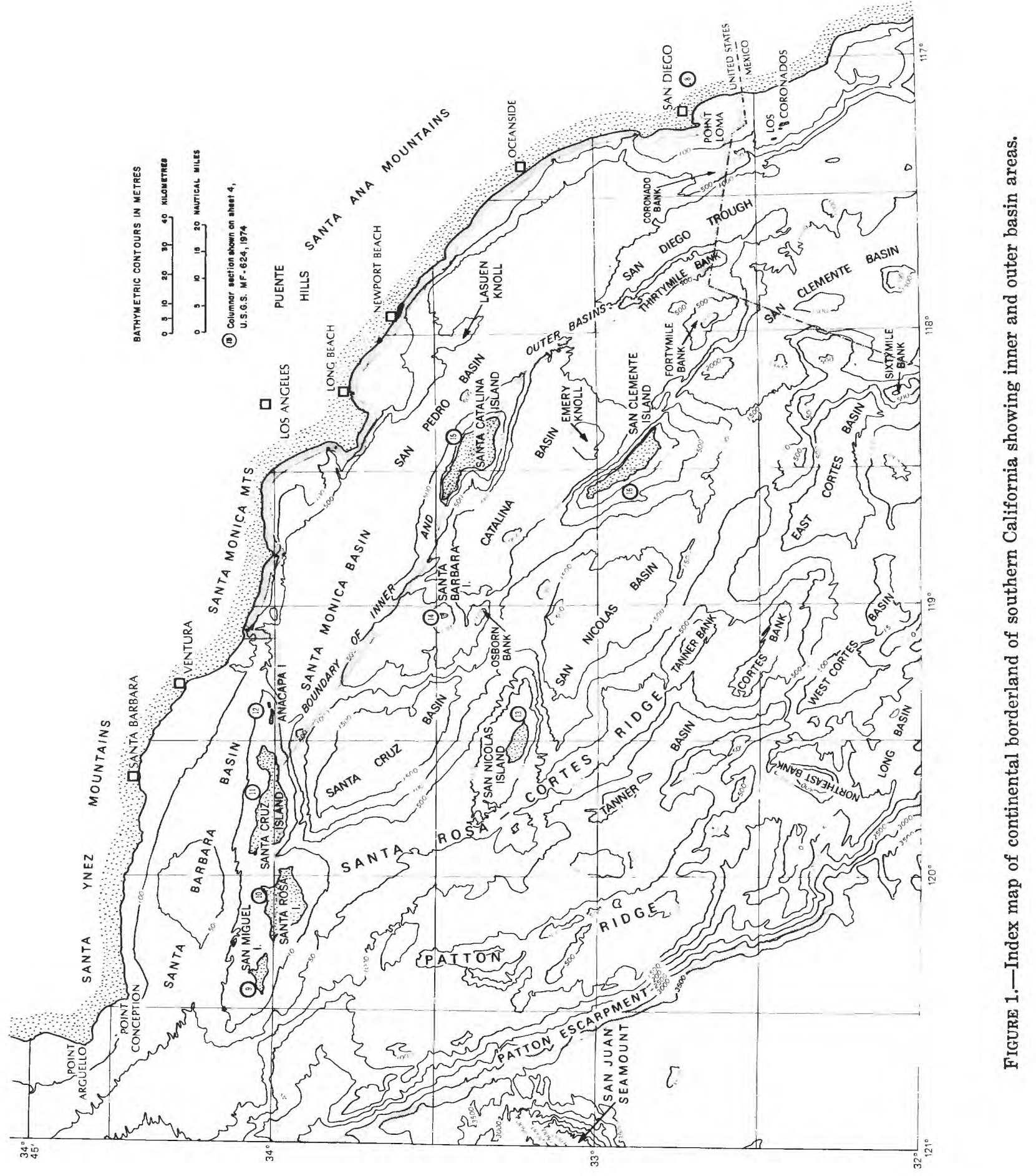


anticlines and local intense folding, thrust faulting, and local unconformities. This structural style (Wilcox and others, 1973), which reflects the movements along the San Andreas fault, decreases eastward into the center of the San Joaquin basin. The Sierra Nevada granitic block and its continuation under much of the Great Valley had a pronounced stabilizing effect on the overlying sediments deposited during Tertiary time. In contrast, the entire area west of the San Andreas fault was intensely deformed, and each of the resulting Tertiary basins had its own unique tectonic and depositional history.

The Late Cretaceous and Cenozoic history of the onshore area west of the San Andreas can be divided into two intervals: from Late Cretaceous to the end of Paleogene time, and from early Miocene time to the present. The earlier interval began with local sedimentation in Late Cretaceous time after extensive erosion of the basement complex. Remnants of these Cretaceous sediments are now best exposed in the northern Transverse Ranges, the Santa Monica Mountains, and on the flanks of the Peninsular Ranges, which extend from the Los Angeles region south into Baja California. Extensive subsidence and deposition occurred during Paleogene time. Deep-water Eocene sediments were deposited over much of what is now the western Transverse Ranges, the Santa Barbara Channel, and the San Diego area and farther north in the Coast Ranges south of San Francisco. They also occur in the northern Channel Islands and San Nicolas Island. After gradual filling of these marine basins, regional uplift, erosion, and continental deposition occurred in Oligocene time and locally extended into early Miocene time.

The second interval began in early Miocene time with the deposition of shallow-water sands of the Vaqueros Formation during the beginning of a major marine transgression. The transgressive sands were overlain by the most widespread accumulation of deep-water shale in all the Pacific west coast. These rocks include the early to middle Miocene Rincon Shale, ${ }^{1}$ the Miocene Monterey Formation, and late Miocene shales represented by the Sisquoc, Puente,

\footnotetext{
1 The Oligocene-Miocene boundary is in dispute, but for this paper it is considered to occur within the Zemorrian Stage. Con sequently, the Vaqueros and Rincon Formations are considered no older than early Miocene.
}

Modelo, and Capistrano Formations. The Monterey typically includes large percentages of siliceous shale and diatomite as well as dolomitic, calcareous, and phosphatic shale. Early Miocene time also marked the beginning of extensive volcanism, increased tectonism with downwarpings of basins of more limited size than characterized the Paleogene, and renewed and continuing strike-slip movements on major faults, especially on the San Andreas fault (Clarke and Nilsen, 1973). During late Miocene and Pliocene time the Los Angeles and Ventura basins subsided rapidly, accumulating thick deposits of bathyal sediments derived from adjacent uplifted areas. Most of these Neogene basins approximate those that exist today but were modified by intense deformation during Pliocene and Pleistocene time. This second interval is still in progress; some of the basins are completely filled, others such as the Los Angeles, Ventura, and Santa Maria basins are nearly filled on their landward margins, and others are only partly filled, such as some on the borderland where present sedimentation is occurring at bathyal depths in excess of $1,000 \mathrm{~m}$ $(3,280 \mathrm{ft})$.

\section{OIL AND GAS IN ONSHORE CALIFORNIA BASINS}

The distribution of oil and gas in California basins on the basis of cumulative production plus demonstrated reserves ${ }^{2}$ in known fields is shown in figure 2. The state's total oil production to January 1,1975 , has been 16,753 million barrels, and demonstrated reserves include measured reserves (3,557 million barrels) and indicated reserves (1,349 million barrels) for a current estimate of recoverable oil expected to total 21,659 million barrels (American Petroleum Institute, API, 1975). These estimates include only reserves from known fields; they do not include inferred reserves, ${ }^{2}$ reserves in discovered but as yet unproduced fields, future discoveries of new fields, or additional recoveries resulting from technological advances in recovery methods or significant changes in economic conditions.

To evaluate the distribution of petroleum in

\footnotetext{
${ }^{2}$ For definition of terms see table of contents at beginning of report.
} 
California basins and specifically the fields in the coastal basins, cumulative production figures to January 1, 1975, have been used rather than current estimates of total recovery or estimates of original-oil-in-place. Reserve figures which are necessary for estimating total recovery (that is, cumulative production plus measured reserves), are published only for entire state (API, 1975) and for those fields with recoveries expected to exceed 100 million barrels of oil (Oil and Gas Journal, 1975a). If measured reserves for all fields were available, a ranking of fields based on estimated recoveries would not be appreciably different from that based on cumulative production, nor would this data change the percentage of total recoverable oil attributed to the largest fields. Published figures show that the 42 largest fields in California (Oil and Gas Journal, 1975a) have reserves of 4,109 million barrels, or 84 percent of the 4,906 million barrels of reserves from all California fields. Original oil-in-place is reported (API, 1975, p. 29-32, p. 75) for the state, but there are no figures for individual fields in California.

Secondary recovery is increasingly important to current oil production in California, with portions of 102 fields undergoing water-flooding and 75 low-gravity fields being stimulated by steam and (or) hot water injection. Secondary recovery by steam now accounts for 34 percent of the present annual production in California (Conservation Committee of California Oil Producers, CCCOP, 1975, p. B). Most of the fields with low-gravity crude contributing to this percentage are in the San Joaquin Valley; the San Ardo field is the major contributor of the fields in the coastal region (CCCOP, 1975, table XXIII-B). The indicated additional reserves of 1.3 billion barrels of oil reported by the American Petroleum Institute reflect the importance of planned and future secondary recovery programs from known fields within the state.

\section{OIL AND GAS IN CALIFORNIA COASTAL BASINS}

Over one-half of the cumulative production (and estimated recovery) in California basins is attributed to the coastal basins west of the San Andreas fault (fig. 2). In the accompanying tables on field and basin statistics, cumulative production plus demonstrated reserves are available only for the largest fields. Therefore, cumulative production has been used. Because our concern is how much energy might be derived from the borderland, produced gas has been converted to BOE (barrels of oil equivalent), assuming that $6,000 \mathrm{ft}^{3}$ of gas has the approximate BTU value of one barrel of oil. This conversion allows an easy comparison between gas, oil, and oil and gas fields. The tables list both cumulative production of oil and oil plus BOE. For comparative purposes, the distribution of petroleum in the coastal basins is reviewed not only by basin but also by field size, stratigraphic age of the reservoir, the reservoir rock type, and the traps in which this oil and gas occurs. Offshore resources would be expected to be found in similar situations if offshore and onshore basins are truly analogous.

The amount of petroleum decreases in the coastal basins from south to north (figs. 2 and $3)$. The Los Angeles basin has accounted for 37 percent of the state's total production and 66 percent of the total production of the coastal basins. The Ventura basin is next in size with 22 percent of the total production from the coastal basins, followed by Santa Maria basin with 6 percent, Cuyama basin with 3 percent, and Salinas and other coastal basins with a total of 3 percent. The geology that affects this distribution needs to be understood; otherwise the proximity of the Los Angeles and Ventura basins with 88 percent of the petroleum may unduly influence the estimates of potential petroleum resources in the borderland.

\section{DISTRIBUTION OF PETROLEUM IN COASTAL BASINS}

\section{FIELD SIZE}

The magnitude of the estimated resource of any basin or frontier area such as the borderland will depend on discovery of major fields. Most of the total world discovered resources, including those in North America, are in giant fields (greater than 500 million barrels) (Moody and others, 1970). This distribution is also true for California basins (tables 5-9). Some major characteristics of the fields in the coastal basins west of the San Andreas fault 


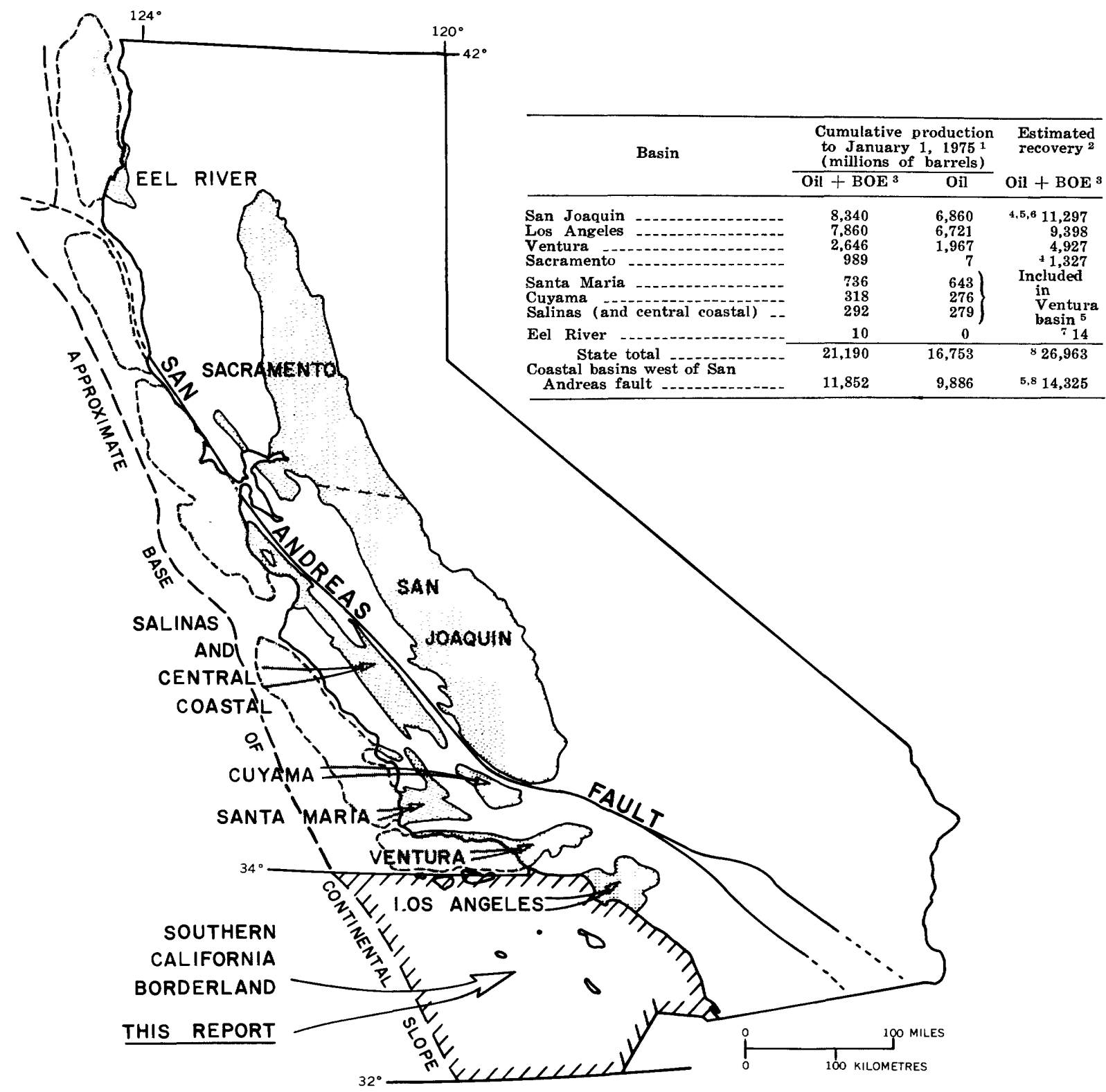

Figure 2.- (See caption at top of facing page.) 
FIgURE 2.-Cumulative production and estimated recovery ${ }^{2}$ of oil and gas ${ }^{3}$ from fields in onshore and offshore $^{8}$ basins of California. Late Tertiary offshore basins in the Outer Continental Shelf (OCS) area north of the borderland are outlined.

1 Compiled from Conservation Committee of California Oil Producers (CCCOP, 1975).

2 Estimated recovery is sum of cumulative production plus estimated reserves compiled by American Petroleum Institute (API, 1975). These include: estimated proved oil reserves plus indicated additional oil reserves (API, 1975, p. 14, 23), and estimated total proved reserves of natural gas (API, 1975, p. 102, 114) equated to barrels of oil equivalent (see 3 ), all from known reservoirs.
3 Gas equated to oil on approximate BTU energy equivalent, that is. $6,000 \mathrm{ft}^{3}$ of gas equals one barrel of oil (BOE=barrel oil equivalent).

${ }^{*}$ Nonassociated gas reserves (as BOE) allocated on past production ( 88 percent for Sacramento basin, 11 percent for San Joaquin basin, and 1 percent for Cuyama basin).

5 Cuyama basin's remaining oil and associated gas reserves included in San Joaquin basin total.

6 Oil and associated gas from the Brentwood field included in total for San Joaquin basin.

7 Estimated remaining gas reserves, from California Div. Oil and Gas $(1975$, p. 132$)$.

8 Reserves do not include discovered but as yet not produced offshore fields in Federal waters in the Santa Barbara Channel: Santa Ynez Unit; Santa Clara Unit; Pitas Point Unit.

BASINS AND \% OF PRODUCTION

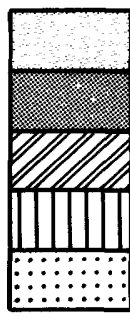

LOS ANGELES
VENTURA
SANTA MARIA
CUYAMA
SALINAS

\begin{tabular}{rr}
\hline $66 \%$ \\
$22 \%$ \\
$6 \%$ \\
$3 \%$ \\
$3 \%$
\end{tabular}

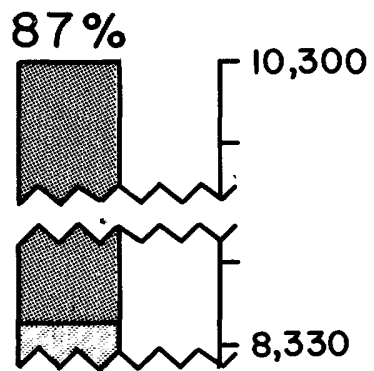
SALINAS
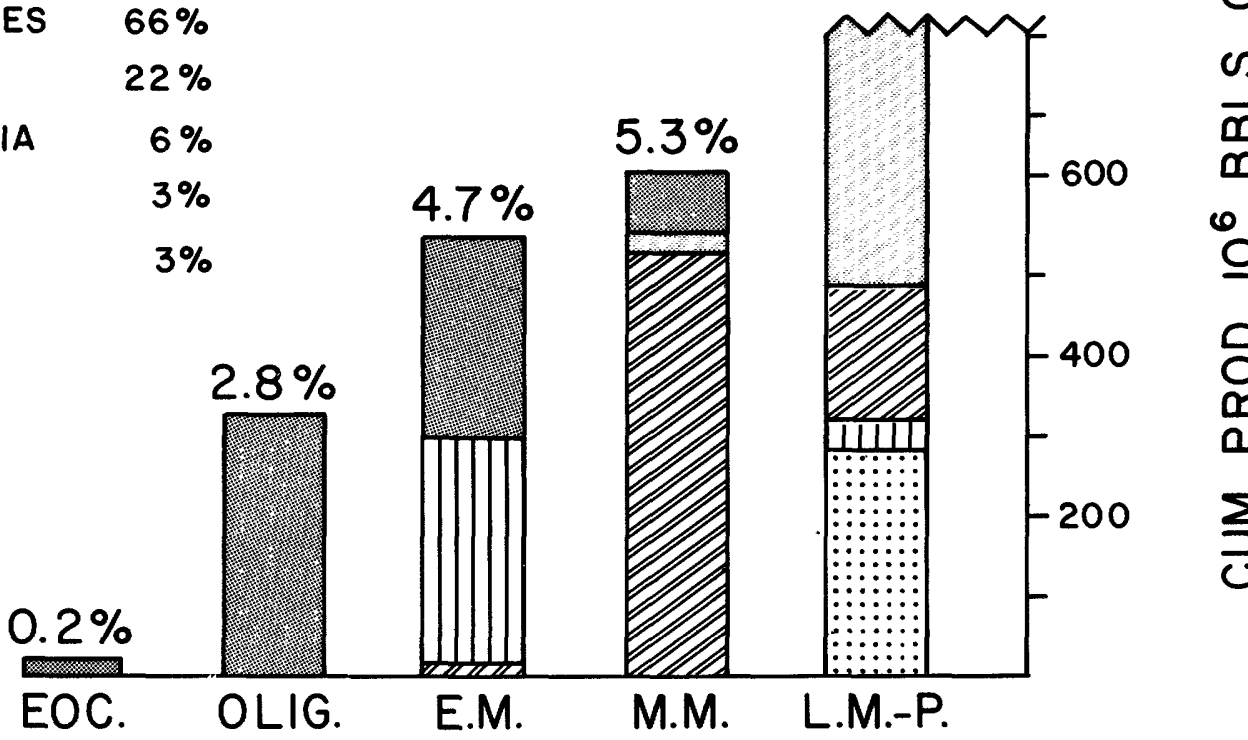

\section{INCREASING AGE}

FiguRE 3.-Histogram of cumulative production by age and basin for basins west of the San Andreas fault. Cumulative production is to January 1, 1975, and is expressed in billions of barrels of oil plus BOE (gas to barrels of oil equivalent). See table 2 for values and references. EOC, Eocene time, OLIG, Oligocene; E.M., early Miocene time; L.M., late Miocene time; P, Pliocene time.

are listed in table 1. A cumulative curve (fig. 4) shows the dominance of the five giant fields which account for $\mathbf{5 2}$ percent of the total oil produced. The distribution of the fields on the plot is approximately log normal. Some fields with continuous structures and reservoirs that have been considered as separate fields because of their discovery and (or) development history, are grouped as one field in this report; this includes the two largest fields shown on table 1 . 
TABLE 1.-59 largest fields in coastal basins west of San Andreas fault

[Ranked by cumulative production, showing current estimates of total recovery (where available) and main characteristics]

Field and basin: C, Cuyama; LA, Los Angeles; S, Salinas; SM, Santa Maria; V, Ventura:

Cumulative production to 1-1-75: BOE-barrels oil equivalent of gas at approximate BTU energy value, 6,000 $\mathrm{ft}^{3}$ gas=one

Current estimate of total recovery: From American Petroleum Institute estimates of remaining reserves for fields with "ultimate recoveries" greater than 100 million barrels oil (Oil and Gas Journal, 1975a).
Cumulative percent of basin total: Based on cumulative production of oil plus BOE to January 1, 1975.

Main reservoir type: DM sd, deep-marine sand; SM sd, shallowmarine sand; $C$ sd, continental sand; $F$ sh, fractured shale; cgl, conglomerate.

Trap type: A, anticline; D, dome; H, homocline; N, nose; F, fractured; $S$, stratigraphic variations, pinch-outs, permeability seals.

Barrels per acre recoveries: Based on cumulative production of oil plus BOE to January 1, 1975.

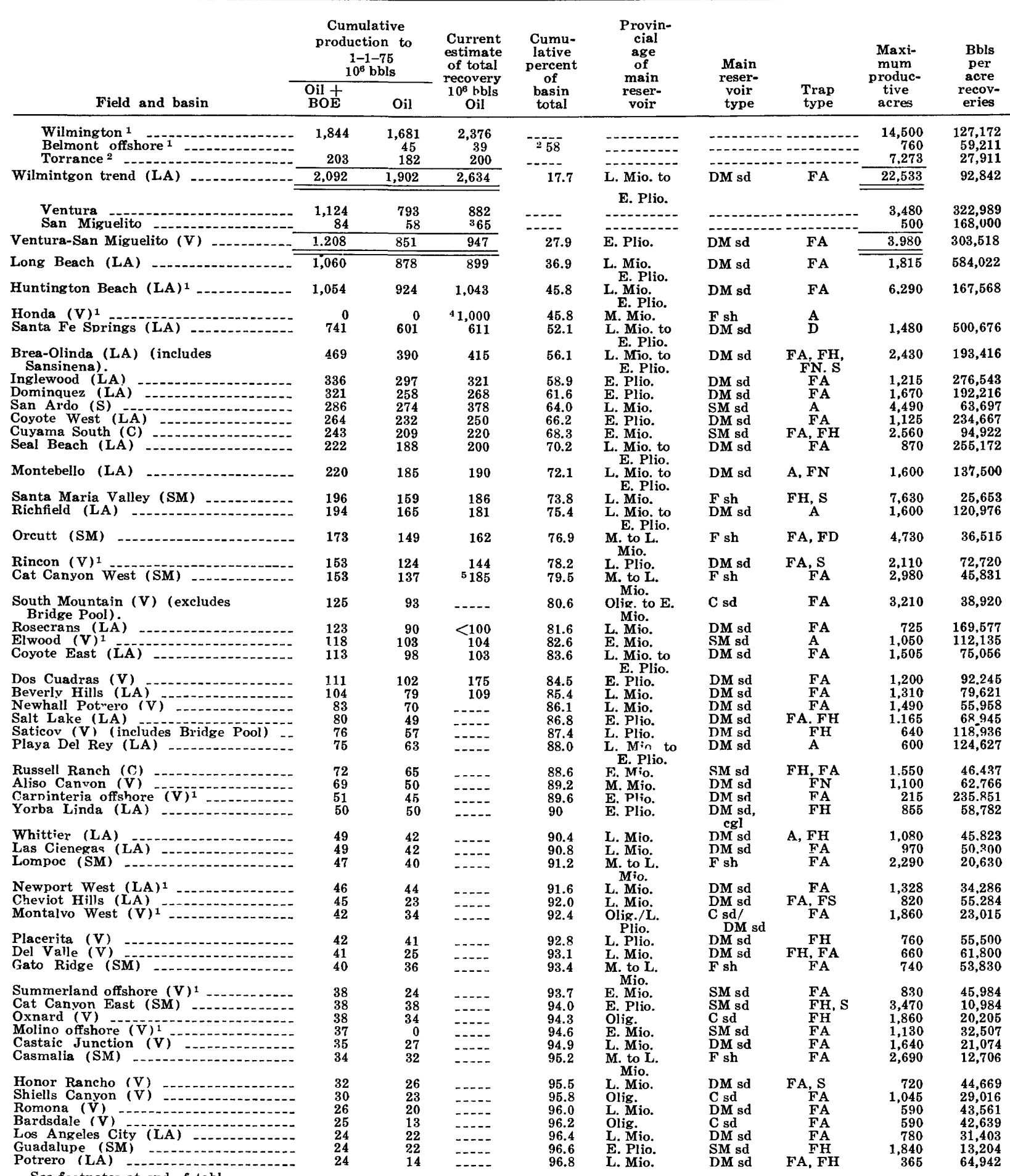




\begin{tabular}{|c|c|c|c|c|c|c|c|c|c|}
\hline \multirow[b]{2}{*}{ Field and basin } & \multicolumn{2}{|c|}{$\begin{array}{c}\text { Cumulative } \\
\text { production to } \\
1-1-75 \\
10^{6} \mathrm{bbls} \\
\end{array}$} & \multirow{2}{*}{$\begin{array}{c}\text { Current } \\
\text { estimate } \\
\text { of total } \\
\text { recovery } \\
10^{\circ} \mathrm{bbls} \\
\text { Oil }\end{array}$} & \multirow{2}{*}{$\begin{array}{c}\text { Cumu- } \\
\text { lative } \\
\text { percent } \\
\text { of } \\
\text { basin } \\
\text { total }\end{array}$} & \multirow{2}{*}{$\begin{array}{c}\text { Provin- } \\
\text { cial } \\
\text { age } \\
\text { of } \\
\text { main } \\
\text { reser- } \\
\text { voir }\end{array}$} & \multirow{2}{*}{$\begin{array}{l}\text { Main } \\
\text { reser- } \\
\text { voir } \\
\text { type }\end{array}$} & \multirow[b]{2}{*}{$\begin{array}{c}\text { Trap } \\
\text { type }\end{array}$} & \multirow{2}{*}{$\begin{array}{l}\text { Maxi- } \\
\text { mum } \\
\text { produc- } \\
\text { tive } \\
\text { acres }\end{array}$} & \multirow{2}{*}{$\begin{array}{l}\text { Bbls } \\
\text { per } \\
\text { acre } \\
\text { recov- } \\
\text { eries }\end{array}$} \\
\hline & $\begin{array}{l}\text { Oil t } \\
\text { BOE }\end{array}$ & Oil & & & & & & & \\
\hline Conception offshore (V) ${ }^{1}$ & 23 & 21 & $-\cdots$ & 97.0 & Olig. E. & SM sd & FA & 330 & 69,973 \\
\hline $\begin{array}{l}\text { Sespe Canyon Group (V) } \\
\text { Capitan (V) }\end{array}$ & $\begin{array}{l}22 \\
22\end{array}$ & $\begin{array}{l}20 \\
19\end{array}$ & $-\cdots$ & $\begin{array}{l}97.2 \\
97.4\end{array}$ & $\begin{array}{l}\text { Mio. } \\
\text { olig. } \\
\text { Olig./E. } \\
\text { Mio. }\end{array}$ & $\begin{array}{l}\text { C sd } \\
\text { C sd/ } \\
\text { SM sd }\end{array}$ & $\underset{\text { FD }}{\text { FH, FA, FS }}$ & $\begin{array}{r}2,030 \\
330\end{array}$ & $\begin{array}{l}10,791 \\
66,167\end{array}$ \\
\hline \multirow[t]{3}{*}{$\begin{array}{l}\text { Torrey Canyon (V) } \\
\text { Zaca Creek (SM) }\end{array}$} & $\begin{array}{l}22 \\
21 \\
\end{array}$ & $\begin{array}{l}18 \\
20 \\
\end{array}$ & 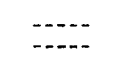 & $\begin{array}{l}97.6 \\
97.8\end{array}$ & $\begin{array}{l}\text { Olig. } \\
\text { M. to } \mathrm{L} \text {. }\end{array}$ & $\begin{array}{l}\text { C sd } \\
\text { F sh }\end{array}$ & $\begin{array}{l}\text { FD } \\
\text { FH }\end{array}$ & $\begin{array}{l}260 \\
490\end{array}$ & $\begin{array}{l}83,700 \\
42,649\end{array}$ \\
\hline & $\begin{array}{r}11,551 \\
\quad 301 \\
\end{array}$ & $\begin{array}{r}9,657 \\
229 \\
\end{array}$ & 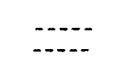 & $-\cdots \overline{2} . \overline{2}$ & 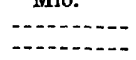 & - & 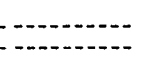 & $-\cdots$ & - \\
\hline & 11,852 & 9,886 & ${ }^{6} 12,153$ & 100 & 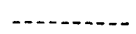 & - n. & - - - - - - - & $\ldots$ & $\ldots$ \\
\hline
\end{tabular}

1 All or part of field in offshore.

2 From National Petroleum Council (McCaslin, 1975).

3 No data; calculated as percent of cumulative production.

No data; calculated as percent of cumulative production.

${ }^{4}$ Undeveloped major field in Santa Ynez Unit. Reserves estimated at 94,000,000 bbls by American Petroleum Institute (Oil and Gas Journal, April 31, 1975); 1-3 billion for Santa Ynez Unit (Oil and Gas Journal, January 27, 1975); and 3 billion for Santa Ynez Unit by National Petroleum Council (McCaslin, 1975).

"Remaining reserves of 48 million barrels includes those for Cat Canyon East.

"Estimated "ultimate recovery" based on cumulative oil production to January 1, 1975 plus API estimates (1975) of oil reserves plus indicated additional reserves from known oil fields.

Most of the production from the 18 largest fields (greater than 100 million BOE) has come from the Los Angeles basin.
Thorough exploration in California has probably found all of the giant fields that exist onshore. The remaining undiscovered oil onshore

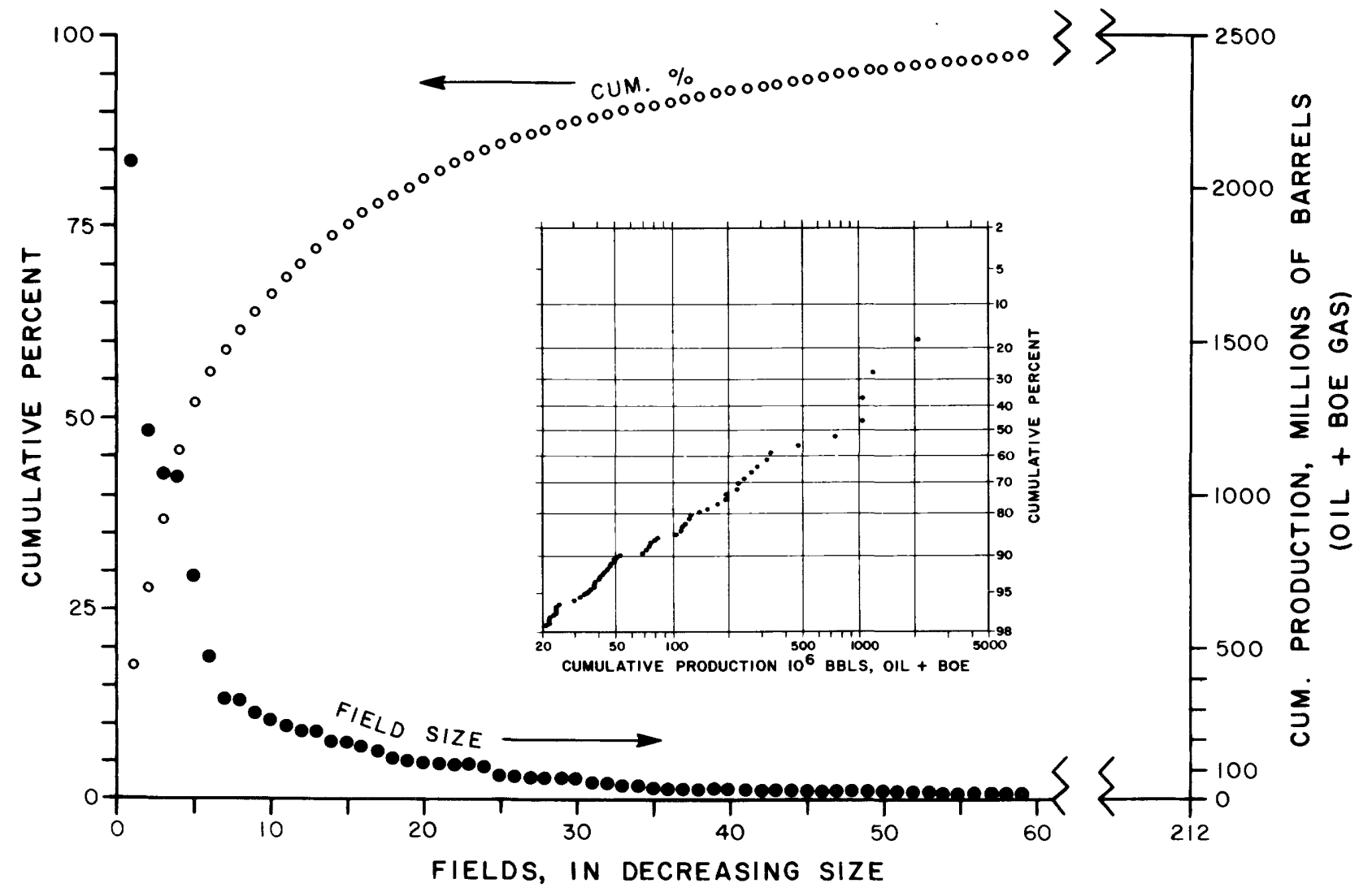

Figure 4.-Size distribution of fields larger than 20 million barrels in basins west of the San Andreas fault. Fields are plotted in order of decreasing size and by cumulative percent of the total production in these basins. The insert shows the cumulative distribution on logarithmic scale. Note that the plot follows a linear trend indicating a $\log$ normal distribution. Field size is based on cumulative production to January 1, 1975. Barrels are expressed as barrels of oil plus gas as barrels of equivalent oil (see text). 
is not expected to significantly vary the field size distribution and will not appreciably increase the current estimates of 21,659 million barrels of recoverable oil. This conclusion is supported by the low discovery rate of new fields in the coastal basins over the past few decades and the current estimated recoveries from those new fields (American Petroleum Institute, 1975). In the last 20 years new reserves have accounted for 1.2 billion barrels of oil plus BOE, which amount to only 8.3 percent of the estimated recoverable reserves in the coastal basins. This is true despite the fact that most of these discoveries came from areas not previously available for exploration; the state lands in the Santa Barbara Channel; the urbanized areas of Los Angeles (McFarland and Greutert, 1971) ; and San Pedro Bay (exclusive of Wilmington, which was discovered in 1932). The analogous coastal basins now account for 56 percent of California's total cumulative production, but this percentage should increase as production increases from newly discovered but as yet unproduced fields in the Santa Barbara Channel, such as the Santa Ynez Unit, where reserves are estimated as high as 3 billion barrels (McCaslin, 1975, p. 232), and the newly discovered Santa Clara Unit.

\section{AGE}

The concentration of oil in the late Miocene and younger reservoirs in California basins has often been noted. Table 2 shows the distribution of petroleum production by chronostratigraphic age in the coastal basins west of the San Andreas fault.

A histogram (fig. 3) reemphasizes the high percentage attributed to these late Miocene and younger reservoirs; 87 percent or 10,307 million barrels (oil $+\mathrm{BOE}$ ). Oil reserves decrease markedly with the age of the reservoir, and the Eocene reservoirs have only 0.2 percent of the total (approximately 19 million barrels), which is concentrated in the eastern Ventura basin. The Oligocene reservoirs (2.8 percent or 329 million barrels), occur in fields in the Ventura basin; most oil (303 million barrels) is found in fields on the south flank of the basin onshore and a smaller concentration (26 million barrels) occurs along the northern coast of the Santa Barbara Channel, mainly in the Elwood and Capitan fields. Early Miocene reservoirs (4.7 percent or 555 million BOE) are found almost entirely in two areas, the fields along the north side of the Santa Barbara Channel (253 million barrels) and those in the Cuyama basin (282 million barrels). Most of the middle Miocene production (5.4 percent or 642 million barrels) comes from fractured siliceous shale in the Santa Maria basin, (with minor production from fractured shale in the Los Angeles basin) and from sandstone reservoirs in the eastern Ventura basin. Very little sand was deposited during this period of widespread marine transgression, but some is found locally adjacent to the few elevated areas that remained positive during this period. Recent discoveries in the Santa Ynez Unit will increase the per-

TABLE 2.-Distribution of petroleum by stratigraphic age for coastal basins west of the San Andreas fault [Based on cumulative production to January 1, 1975, in million of barrels, oil plus BOE gas]

\begin{tabular}{|c|c|c|c|c|c|c|}
\hline Basin & Eocene & Oligocene & $\begin{array}{c}\text { early } \\
\text { Miocene }\end{array}$ & $\begin{array}{c}\text { middle } \\
\text { Miocene }\end{array}$ & $\begin{array}{c}\text { late } \\
\text { Miocene } \\
\text { or } \\
\text { younger }\end{array}$ & Total \\
\hline Los Angeles ${ }^{1}$ & 0 & 0 & 0 & 20 & 7,840 & 7,860 \\
\hline Ventura total & 19 & 329 & 259 & 68 & 1,971 & 2,646 \\
\hline Eastern onshore ${ }^{2}$ & 18 & 303 & 6 & 65 & 1,805 & $-\ldots$ \\
\hline Santa Barbara ${ }^{3}$ & 1 & 26 & 253 & 3 & 166 & ---- \\
\hline Santa Maria ${ }^{4}$ & 0 & 0 & 14 & 555 & 170 & 736 \\
\hline Cuyama $^{5}$ & 0 & 0 & 282 & 0 & 36 & 318 \\
\hline Salinas $^{5}$ & 0 & 0 & 0 & 2 & 290 & 292 \\
\hline Total & 19 & 329 & 555 & 642 & 10,307 & 11,852 \\
\hline Percentage of total & 0.2 & 2.8 & 4.7 & 5.4 & 87.0 & 100 \\
\hline
\end{tabular}

1 Percentages from Gardett (1971, p. 303).

a Percentages derived from ultimate recoverable reserves (Nagle and Parker, 1971).

3 Percentages and age designation derived from Conservation Committee of California Oil Producers (1975) and California Division of Oil and Gas (1974).

4 Percentages from Crawford (1971).

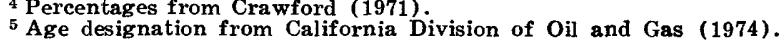


centage of production from these middle Miocene reservoirs, for fractured shale is the main reservoir in the Hondo field, the largest field in this unit (U.S. Geological Survey, 1974).

Considering the tectonic activity that occurred during middle and late Miocene time, the distribution of pre-middle Miocene reservoirs may have a marked bearing on potential size and location of reservoirs of similar age in the borderland. These reservoirs are almost entirely within the Ventura and Cuyama basins; the greatest amount of oil and gas has been discovered in the widespread Vaqueros Formation and lesser amounts in the Sespe and Alegria Formations. Both reservoirs occur on the perimeter of what is considered the thickest Eocene section west of the San Andreas fault, at least $5,340 \mathrm{~m}(17,500 \mathrm{ft})$ thick (Dickinson, 1969). The Paleocene(?) and Eocene rocks in the Sierra Madre Mountains may exceed 7,600 m $(25,000 \mathrm{ft})$ in thickness (Vedder, 1968). Although the U.S. Geol. Survey has done no source-rock studies in these areas, the wellindurated dark-gray to gray-black shales that are common in the Cozy Dell Shale and Juncal Formation could be possible source rocks for the oil in the pre-middle Miocene reservoirs. Bailey (1947) recognized that Eocene rocks might be the source for oil in the nonmarine Sespe Formation, and this interpretation is also reasonable for the entire sequence of Eocene, Oligocene, and early Miocene reservoirs.

The widespread early Miocene sandstone reservoirs of the Vaqueros Formation were blanketed by thick marine shale, an excellent cap rock for any newly generated oil. Increased tectonism toward the end of middle Miocene time undoubtedly produced structural traps. The present structural traps containing Oligocene and lower Miocene petroleum may be modifications of these earlier Miocene structures, or some may be only recently formed. Because of the continuity of the Vaqueros reservoir sands and the thick cap rock, widespread remigrations may have occurred as older structures were modified, lost their volume of closure, and spilled oil that may have migrated to other structural traps at positions around the margin of the basin.

Another striking feature of these reservoirs is the cluster of dry gas fields in the western
Santa Barbara Channel, the La Goleta, Naples, Molino, Gaviota, and Caliente fields. These have produced 62 million BOE. Dry gas is not common in these coastal basins, and it might be late-generated gas (Pussey, 1973; Hunt, 1974) from the nearby deeply buried Eocene (and Upper Cretaceous?) section. In some recent reconstructions of Paleogene paleogeography, the Transverse Ranges and the Cuyama block were little affected by the breakup and major lateral adjustments attributed to other areas in central and southern California (Howell, 1975; Clarke and Nilsen, 1973; Nilsen and Clarke, 1975). Such adjustrnents, even though debatable in magnitude, timing, and direction, are generally conceded to have occurred, and existing oil and gas fields may have been destroyed in areas more affected by this tectonism.

\section{RESERVOIR ROCK TYPE}

Reservoir rocks in the coastal basins consist of marine deep-water and shallow-water sands, nonmarine alluvial and deltaic sands, and fractured siliceous shale. Fragmented schist basement is a minor producer but is insignificant as a contributor to total petroleum discovered onshore and is therefore not a primary objective in the borderland. These rocks can be generally grouped by stratigraphic age. Deep-water sands are predominant in the late Miocene and younger reservoirs. They are almost totally restricted to the Los Angeles and Ventura basins where the late Miocene to Pliocene basin subsidence was great, allowing a thick buildup of these thin-bedded, generally fair-sorted sands. Total stratigraphic thickness of reservoirs approaches $2,000 \mathrm{~m}(6,500 \mathrm{ft})$ in the Ventura and Santa Fe Springs fields. With reservoir sands typically accounting for up to 40 percent of the productive stratigraphic interval, net productive sand commonly exceeds $1,000 \mathrm{~m}(3,280 \mathrm{ft})$ in thickness. These extremely thick net-pay intervals have yielded some of the highest barrels per acre recoveries onshore (table 1 ). This reservoir rock probably accounts for about 80 percent of the total oil in the coastal basins (table 2 and fig. 4).

The best reservoir rocks are shallow-water, high-energy sandstone, the most productive of which was deposited during the early Miocene 
transgression. These rocks account for more than 10 percent of the total production in the coastal basins. The Vaqueros Formation, widespread in the western Ventura basin and extending northeasterly into the Cuyama basin, is productive in these two areas but is nonproductive in the southeastern Los Angeles basin where the underlying Eocene rocks are relatively thin. This reservoir has yielded over 500 million barrels (oil $+\mathrm{BOE}$ ), and the two largest fields, Cuyama South (more than $120 \mathrm{~m} \mathrm{(400}$ ft) thick) and Elwood (more than $90 \mathrm{~m} \mathrm{(300}$ ft) thick) have accounted for nearly 75 percent of the production from the Vaqueros Formation. Similar shallow-water sands of late Miocene age occur in the Salinas Valley in the San Ardo field (Baldwin, 1971), a near giant in an otherwise sparsely productive basin. Early Pliocene shallow to possible outer neritic sands of the Sisquoc Formation are productive over the northern part of the Santa Maria Basin (Crawford, 1971). Many of the reservoirs in the Sisquoc Formation have low-gravity crude oil and are being developed by intense steam soaking. Although this is successful on land, present methods would probably be uneconomic in the offshore.

Fractured shale reservoirs commonly are overlooked as a viable and worthy prospect for exploration, yet they are the third most important reservoir rock in the coastal basins. More than 5 percent of the oil produced in the coastal basins occurs in these rocks. The main reservoir in the recently discovered Hondo field in the Santa Barbara Channel is the massive chert section of the Monterey Formation in which the estimated recoverable reserves may exceed 1 billion barrels. In the Santa Maria basin, the Monterey Formation has yielded 75 percent (540 million BOE to January 1, 1975) of the oil produced in that basin (Crawford, 1971). This unit is the main reservoir of the Orcutt (172 million BOE), Santa Maria Valley (Monterey production estimated at more than 140 million BOE), West Cat Canyon (137 million BOE), Lompoc (47 million BOE), Gato Ridge (40 million BOE), and Casmalia fields ( 34 million BOE), which are north of the borderland. Production from fractured shale is of minor importance in the Los Angeles basin fields (about 20 million BOE, table 2), where it has been restricted to fields in the southwestern part of the basin. The largest production in this basin will probably come from the recent development of the black shale unit of the " 237 " zone at Wilmington (Truex, 1972).

Petroleum in nonmarine clastic reservoirs is concentrated in the Oligocene Sespe Formation of the Ventura basin (Nagle and Parker, 1971); production from the South Mountain field (125 million BOE) is nearly four times larger than the next group of fields. Reservoirs are scattered westward along the Santa Barbara coast where the nonmarine Sespe grades laterally into marine sands of the Alegria and Gaviota Formations (Curran and others, 1971). Other nonmarine deposits that contain oil are of late Pliocene and Pleistocene age and occur around the margins of nearly filled marine basins, especially in the Ventura and Los Angeles basins. These are scattered accumulations of small volume, but collectively they account for several percent of the oil in the coastal basins.

\section{OIL AND GAS GEOLOGY-SOUTHERN CALIFORNIA BORDERLAND}

The many factors that influence oil occurrence have been recently reviewed by Haun (1975). Only those factors pertinent to the borderland are discussed in this report.

The borderland has been divided both geographically and geologically. The inner basin area (fig. 1) includes basins that are extensions of those onshore, such as Santa Monica and San Pedro basins and the San Diego trough. The outer basin area is seaward of the northwesttrending ridge system that includes Santa Catalina Island and extends to the base of the continental slope.

The physiography of the borderland has been described by Shepard and Emery (1941), Emery (1960), Moore (1969), and Vedder and others (1974). Variation in water depth (more than $1,000 \mathrm{~m}(3,280 \mathrm{ft})$ in many basins) has a large influence on the potential recoverable petroleum resources. Sea floor relief has also restricted the type and location of geologic data; most dart sampling has been in water depths less than $1,000 \mathrm{~m}$, and the current highresolution seismic systems used by the U.S. Geol. Survey have a maximum operating depth 
of about $500 \mathrm{~m}(1,640 \mathrm{ft})$. Proposed Federal Lease Sale No. 35 is scheduled for the shallower areas where the depths are generally less than $500 \mathrm{~m}$; the lease sales in the deeper waters are not scheduled until June 1977.

Estimates by the U.S. Geol. Survey of the undiscovered but recoverable petroleum resources in OCS areas (Miller and others, 1975) show values for those areas less than $200 \mathrm{~m}$ deep (656 ft). This depth was chosen because it is the approximate break in slope for the continental shelf throughout much of the world, and because industry can develop and produce fields to these depths with present techniques and within a few years after discovery. The deepest existing platform or sea floor completion is in $139 \mathrm{~m}(455 \mathrm{ft})$ of water in the North Sea, although a platform is being constructed for $267 \mathrm{~m}$ (875 ft) of water for the Santa Ynez Unit in the western Santa Barbara Channel and two platforms $372 \mathrm{~m}(1,200 \mathrm{ft})$ high are planned and awaiting construction in the Gulf of Mexico (McNabb, 1975, p. 19).

Of the more than $21,000 \mathrm{mi}^{2}$ in the borderland, only about $2,306 \mathrm{mi}^{2}$ (11 percent) is shallower than $200 \mathrm{~m} \mathrm{(660} \mathrm{ft)} \mathrm{(fig.} \mathrm{5);} \mathrm{this} \mathrm{is}$ equally divided between waters owned by the State of California and the Federal Government. Of the Federal waters, more than 70 percent $\left(849 \mathrm{mi}^{\circ}\right)$ is in the outer basin area and 30 percent is in the inner basin area; 50 percent of the State area is along the mainland coast. The latter area is already productive in San Pedro Bay and Santa Monica Bay and is considered the area in less than 200 metres water depth with the highest potential for additional reserves.

\section{OIL AND GAS SEEPS}

Oil and gas seeps, as well as outcrops of asphalt-impregnated sands, have been used since the early days of oil exploration as indicators for underground accumulations. This is especially true in California oil basins where extensive seeps led to early oil field discoveries before the turn of the century. Offshore seeps in southern California waters have been documented (Wilkinson, 1971, 1972; Fischer and Stevenson, 1973), but these are almost all restricted to the Santa Barbara Channel, exten- sions of the Los Angeles basin into Santa Monica Bay, and Huntington Beach in the San Pedro basin. Several inactive seeps have been reported elsewhere in the Santa Monica basin, such as off the west tip of Santa Catalina Island, off Point Dume, and in the San Pedro Channel.

The absence of documented visible seeps seaward of the Channel Islands cannot be attributed to lack of observation. These waters have been traveled extensively over the last 40 to 50 years by numerous oceanographic institutions, as well as by fisherman, yachtsmen, and more recently oil explorations. In a large part of this area, the Miocene and older rocks have been folded, uplifted, and eroded. Although no major earthquakes greater than magnitude 6 have been recorded, a compilation of events greater than magnitude 4 for the 40 years between 1932 and 1972 shows that the area is seismically active (Hileman and others, 1973). Study of high-resolution seismic records by the U.S. Geol. Survey has revealed offsets on the sea floor, further attesting to the recency of tectonic activity (Greene and others, 1975). Faults with large displacements are also apparent from interpretation of deep-penetration geophysical records, from juxtaposition of dissimilar rocks and rocks of different ages, and to a lesser degree from the geomorphology of the province. These geologic features are similar' to the onshore areas where seeps occur. As a possible indicator of petroliferous basins in the outer basins, the lack of visible seeps is disappointing but in no way eliminates the area as being potential. The U.S. Geol. Survey has not used the more sensitive and interpretative techniques employed by industry, such as fluorescence spectroscopy and gas chromatography of ocean waters and (or) bottom samples.

Bottom sampling by dredging and dart coring has recovered only one dredge haul containing hydrocarbons. In this haul $15-$ to $30-\mathrm{cm}$ slabs of breccia consisting of clasts of late(?) Miocene calcareous and siliceous mudstone and volcanic rocks contain tar in the interstitial pores. This dredge site (KSB $21 \mathrm{E}$ in Vedder and others, 1974) is located 13 nautical miles west of Santa Catalina Island on the steep slope facing northeasterly into the Santa Monica basin. Considering the small volume of ma- 


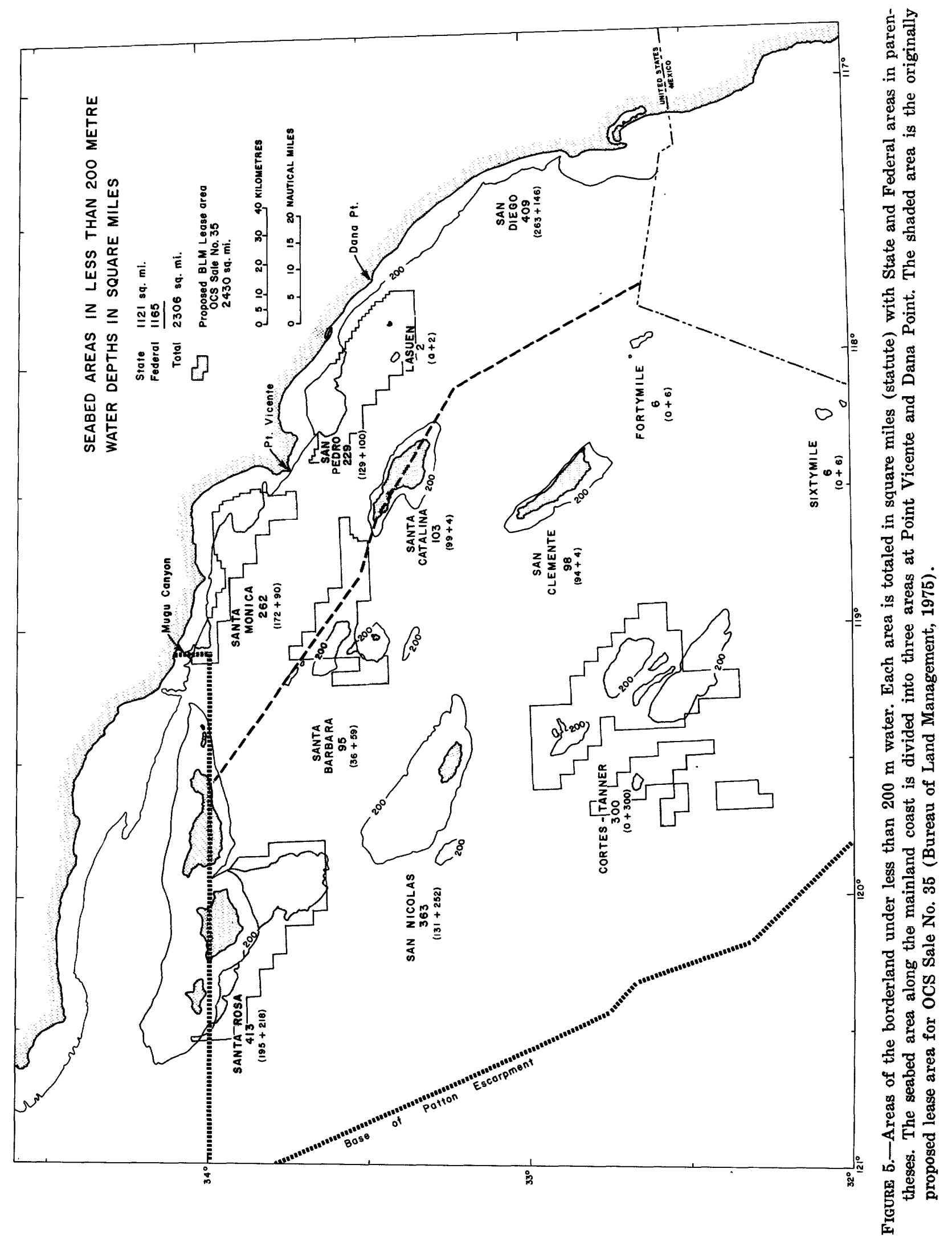


terial retrieved from bottom sampling, the apparent absence of tar-saturated sediments is not considered as significant as the absence of oil and gas seeps.

\section{OFFSHORE WELLS}

One of the factors used in evaluating the oil potential in a frontier area are the "favorable results from, and significance of any exploratory drilling" (Weeks, 1975). Several wells have been drilled on the Channel Islands, 12 on Santa. Rosa and 4 on Santa Cruz (Munger, 1974). The only known reference to oil shows is by Redwine (1955) in Signal-Honolulu well Tecolote No. 1, where "some 20 feet of the basal Sespe were oil-stained, including about one foot of good permeable oil sand containing 45 degree gravity oil." Elsewhere on the borderland, at least 77 core holes and stratigraphic tests were drilled in Federal waters (fig. 6) under permits issued by the California State Lands Commission prior to the Supreme Court's ruling January 31,1966 , on the State-Federal boundary in the offshore waters. The deeper tests were concentrated in San Pedro Bay, and a few were in Santa Monica basin and elsewhere throughout the borderland. According to Munger (1974), 28 core holes penetrated more than 305 $\mathrm{m}(1,000 \mathrm{ft})$ below the sea floor, and $7 \mathrm{ex}-$ ceeded $1,525 \mathrm{~m}(5,000 \mathrm{ft})$. In State waters at least 22 wells were drilled deeper than $1,525 \mathrm{~m}$ (5,000 ft) (fig. 6).

Since 1966, almost all well activity in offshore California has been concentrated outside of the borderland, predominately in the Santa Barbara Channel before and after the OCS lease sale there on February 6, 1968, and to a lesser degree in central and northern California with the OCS sale there in 1963. On the borderland several deep stratigraphic tests were drilled in State waters in 1969 by industry groups, namely off Point Loma, Oceanside, and in Santa Monica Bay. Several industry groups had also drilled over 175 shallow core holes up to $229 \mathrm{~m}$ $(750 \mathrm{ft})$ deep between 1968 and 1975 in the outer basin area, both in and out of the proposed No. 35 sale area, and some were in water depths exceeding $305 \mathrm{~m}(1,000 \mathrm{ft})$. These were drilled under existing rules of the Interior Department administered by the U.S. Geologi- cal Survey. In September 1975, a deep stratigraphic test was spudded off a structure on the southeast flank of Cortes Bank (fig. 6; Lambert zone $6, x=1,152,375, y=108,700$ ). This proposed $3,660-\mathrm{m}(12,000-\mathrm{ft})$ stratigraphic test is one of several such tests drilled or to be drilled on the outer continental shelf of the United States to obtain geologic information for evaluation by both the government and the oil industry prior to lease sale. Geologic permits for the drilling of these wells are issued by the U.S. Geol. Survey under regulations of the Department of the Interior.

Data from these wells are proprietary, but it is known that many of the deeper wells, especially in San Pedro Bay (fig. 6), were drilled on presumably favorable structures, some penetrated at least part of the prospective section, and some had oil and (or) gas shows; it is questionable, however, whether any discovered economic accumulations. If additional information shows that these wells were located on the most favorable structures, were sufficiently deep, and did not penetrate commercial accumulations of petroleum, a large part of the area. with highest potential in the inner basin region must be downgraded.

\section{SEDIMENT THICKNESSES}

A primary concern for frontier areas is whether the basins have adequate thicknesses of sediments for petroleum accumulations. A contour map on the basement surface and an isopach of both postbasement and Pliocene and (or) upper Miocene strata were published by Parker (1971) but were based on limited data. More recent studies (Vedder and others, 1974; Junger and Wagner, unpub. data) have combined seismic profiles with age-dated bottom samples for interpreting the thickness of late Tertiary sediments throughout the borderland. Cross sections, an isopach map of post-Miocene sediments, and a preliminary geologic map as well as sampling on the outer ridges are given in Vedder and others (1974). Two subsequent cruises in 1974 and 1975 by the U.S. Geol. Survey have supplemented and added control in certain areas but have not substantially changed the structural or stratigraphic interpretations as previously published, except in 


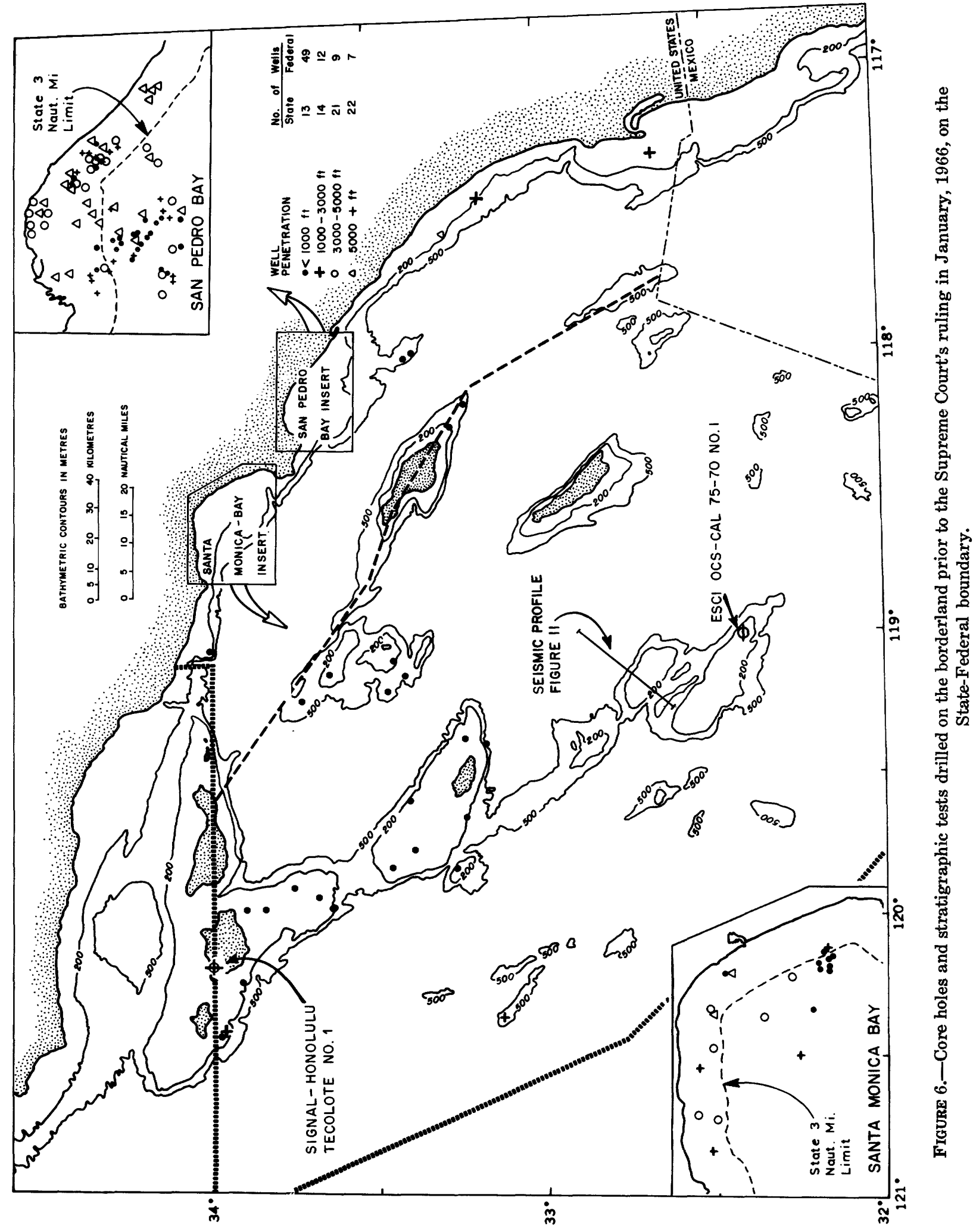


the San Diego Trough where new interpretations have substantially reduced the thickness of post-Miocene sediments. However, previous estimates on the velocities used for calculating these thicknesses have been reduced because of the shallow burial and low compaction evidenced by these post-Oligocene sediments. Consequently, some of the thicknesses published in Vedder and others (1974) are probably excessive by as much as 20 to 25 percent.

The distribution of known Cretaceous sedimentary rocks onshore and in the borderland recently has been reviewed (Vedder and others, 1974). Samples of this age have been identified in sea floor outcrops in only three areas-along the San Diego shelf, west of San Nicolas Island, and on the north edge of the unnamed ridge west of Cortes Bank. The sample from the unnamed ridge has not been previously reported (GSCD $60 ; 32^{\circ} 47.5^{\prime} \mathrm{N}, 119^{\circ} 40.9^{\prime} \mathrm{W}$; Lambert zone $6, x=945,441, y=244,805$ ). Rocks of this age are presumably present just west and southwest of San Miguel Island. Cretaceous sediments are believed to be absent over much of the outer basin area west of the Patton Ridge, and in a broad belt extending southeastward from Santa Cruz Island including Santa Catalina and San Clemente Islands, Thirtymile, Fortymile, and Sixtymile Banks. Their presence under the Santa Rosa-Cortes Ridge adjacent to Santa Cruz and San Nicolas Basins is unknown, but on the basis of seismic records and modeling of gravity data (Sasnett and others, unpub. data), they are thought to be thin, except in the northwesternmost part of the ridge. Rocks of Cretaceous age have been excluded from this evaluation both as a possible source or as reservoir rocks until there is more evidence concerning their presence and character that would substantially differ from that obtained onshore where they have had a negligible productive history.

The Paleogene outcrop and subcrop areas are depicted as a broad belt (fig. 7) that wedges out to the east and probably to the south. Except for some questionable Oligocene sediments, rocks of this age have not been identified in the western third of the borderland. A thickness of $2,150 \mathrm{~m}(7,050 \mathrm{ft})$ of Paleogene sediments is exposed on the Channel Islands, which includes $366 \mathrm{~m}(1,200 \mathrm{ft})$ of continental beds (Sespe type). Another $1,070+m(3,500+f t)$ of deep marine strata of Eocene age was measured on San Nicolas Island, but neither the base nor top is exposed (Vedder and Norris, 1963). The actual thickness in the borderland must be inferred, and gravity modeling (Beyer and others, 1975 ; Sasnett and others, unpub. data) for Bouguer corrections supports the inference already made from weak seismic control that this section, excluding dense Late Cretaceous and possibly early Tertiary rocks, does not exceed $3,350 \mathrm{~m}(11,000 \mathrm{ft})$ anywhere along the Santa Rosa-Cortes Ridge or in the adjacent basins. To the north of the borderland in the northcentral Ventura basin, total Eocene and Oligocene sections have been variously reported to be as thick as $7,600 \mathrm{~m}(25,000 \mathrm{ft})$ (Vedder and others, 1974, map sheet 4; Curran and others, 1971). Thicknesses in the borderland are therefore one-third to one-half of those maximum thicknesses recorded onshore, a major factor in evaluating the potential of the Paleogene rocks.

Neogene sedimentary rocks vary widely in thickness; they are absent or present only as a veneer on many banks and are thickest beneath the floors of the major basins. Over much of the area west of the Santa Rosa-Cortes Ridge, Neogene sediments are believed to lie directly on metamorphic basement. The same is true for the area to the southeast, from Sixtymile Bank northward over Thirtymile Bank to Santa Catalina Island, and they are believed to extend from Fortymile Bank to San Clemente Island and thence to the east end of Santa Cruz Island. On many ridges and banks, the base of the Neogene is traceable on seismic records from the contact on Paleogene rocks at the crests into the flanks and the subsurface sections in the main basins (fig. 11). In the outer basin area, thicknesses to $2,000 \mathrm{~m}(6,500 \mathrm{ft})$ over as much as $50 \mathrm{mi}^{2}$ may occur at the north end of San Nicolas basin and perhaps in the east-central Santa Cruz basin. In contrast, in the Los Angeles basin such thicknesses cover $500 \mathrm{mi}^{2}$, and thicknesses greater than $6,100 \mathrm{~m}(20,000 \mathrm{ft})$ are inferred to cover $250 \mathrm{mi}^{2}$.

Compared to the onshore coastal basins, the thin section of Neogene strata in the outer basin area (and perhaps a large part of the inner basin area as well) is unlike the Los Angeles and Ventura basins in which sedimentary rocks 


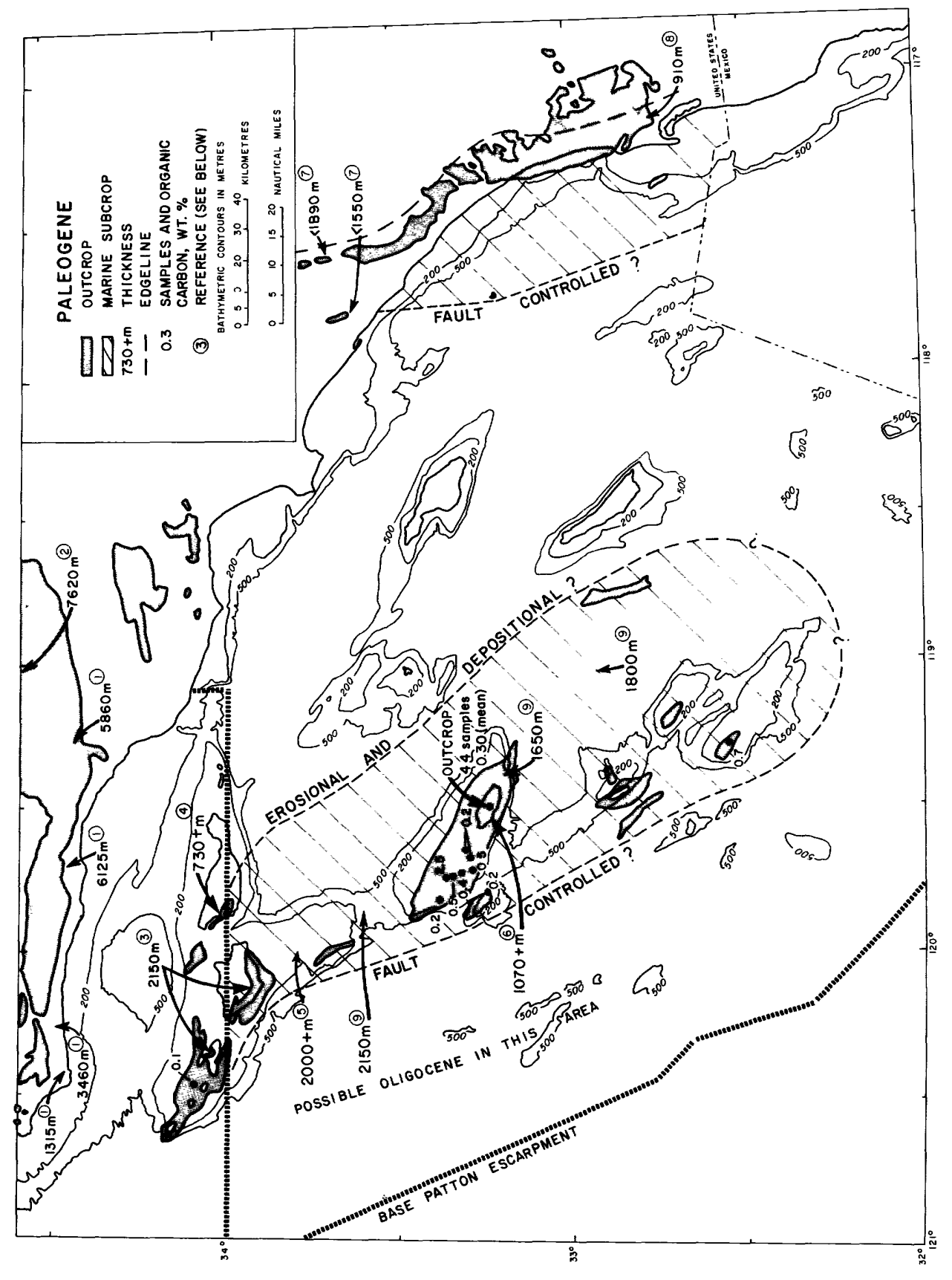

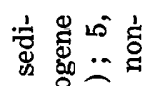

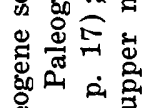

ब

岁揢

象势

要

氙边

范宅

해

สี क्षे

然 $\infty$

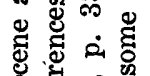

跑

후월

ఫृّ

ฐँ

国

ㄴ.

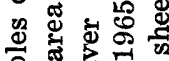

政

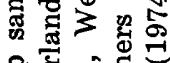

论

열 总

ส

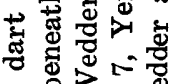

4 3

पित

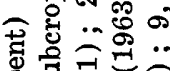

造表

产

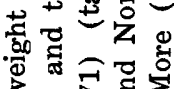

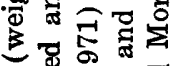

额

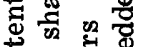

范些》

要 00

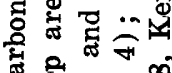

ฮु है है

抣

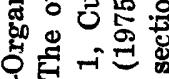

용

-

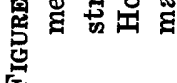


of similar age have produced 83 percent of the total petroleum in the coastal basins (table 2 ). It is similar, however, to the Santa Maria and Salinas coastal basins (from which 1,011 million BOE has been produced), and those basins should perhaps be used as analogs for making assessments of the petroleum potential of the borderland.

In the inner basin area, Paleogene strata are absent except offshore from San Diego (fig. 7). Post-Miocene sedimentary rocks are thickest between Palos Verdes Hills and Santa Catalina Island $(2,200 \mathrm{~m} ; 7,200 \mathrm{ft})$ and in the western Santa Monica basin south of Mugu Canyon $(3,000 \mathrm{~m} ; 9,800 \mathrm{ft})$. However, Junger and Wagner (unpub. data) believe the Miocene sedimentary section is thin to absent beneath these thickest post-Miocene areas of deposition.

Although no volumetric measurements were made on the post-Paleogene sedimentary rocks, these interpretations of thicknesses from recent seismic data supplemented by age-dated dart cores are clearly far less than previously inferred by Parker (1971), whose cross sections show fairly constant thicknesses of up to $3,050 \mathrm{~m}$ (10,000 ft) over Cortes Bank, in San Nicolas, Catalina, and Santa Cruz basins, and $3,660 \mathrm{~m}(12,000 \mathrm{ft})$ in the Santa Monica basin.

\section{POTENTIAL PETROLEUM SOURGE ROCKS}

Over the last few decades, organic geochemistry has contributed greatly to our understanding of petroleum generation. There is a general consensus on the kind and quantity of organic matter required for a sediment to be a potential. source rock, and it is becoming possible to measure the degree of metamorphism of organic material during the interval from its initial burial in sediments to its final stage of graphite (and the release of $\mathrm{CO}_{2}$ ). More is now known of the interrelation between the two main variables in this transformation, namely temperature and time, and many recent studies have typed crude oils and traced these back to their probable original source rock.

As a frontier basin, the borderland has a number of parameters favorable for such studies. The study of Tertiary sediments from sea floor samples is possible because of uplift and erosion after late Tertiary tectonism (Vedder and others, 1974). Much work has been done on analogous and adjacent basins onshore, both from outcrops and wells (Philippi, 1965). Because the inner basin area of the borderland is adjacent to onshore basins and is productive along the coast, our efforts have been concentrated more on the Tertiary sediments seaward of the islands and on the islands themselves.

Selected fine-grained siltstone and mudstone from dart cores and island outcrops, which previously had been paleontologically dated, were analyzed for total organic carbon content, extractable hydrocarbons, and characteristics of those hydrocarbons. The results are listed in tables 10 and 11, and a summary of the results is shown in table 3 . In order to be considered potential petroleum source rocks, argillaceous sediments should contain a minimum content of indigenous organic matter. The lower limit of organic richness for productive basins has been empirically set at 0.4 percent organic carbon (Ronov, 1958; Williams, 1974) and about 100 parts per million extractable heavy hydrocarbons (Philippi, 1957; Baker, 1972). The potential of shale as a source rock is, in general, directly proportional to its organic richness; therefore, sediments that contain more than 5 percent organic carbon and 500 parts per million hydrocarbons can be considered to be excellent potential source rocks.

Samples from Eocene outcrops on San Nicolas Island (table 3) give results consistent with dart cores of similar age from the sea floor (fig. 7). The mean value of the organic carbon from these 54 samples is 0.35 percent, indicating that few of the samples have sufficient organic matter to be considered potential source rocks. Dart cores of Oligocene or Eocene rocks usually can be distinguished from those of Miocene age immediately upon removal from the dart barrel. Fossiliferous silty mudstone of preMiocene age is stiff, in some samples semibrittle, in comparison to soft, plastic Miocene mudstone. They are lighter gray, commonly bluish gray, compared with the dark-gray to brownishblack hues typical of the Miocene rocks. Darker colors ordinarily have been correlated with organic richness, and this has been supported by the analytical data.

Eocene sandstone beds on San Nicolas, on the basis of sedimentary structures, were deposited 


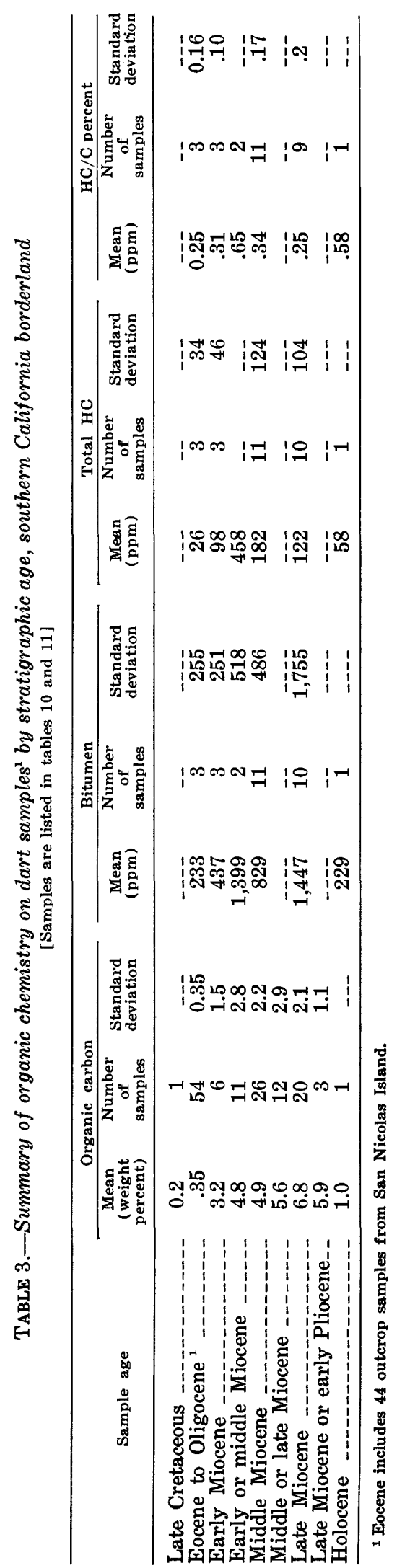


by southwestward directed mass gravity flow (Cole, 1975) into a bathyal environment (Weaver and others, 1969). The interbedded fine-grained siltstone and mudstone are poor source rocks, and the low organic content could be explained by several factors: (1) an oceanographic environment that was not conducive to a rich organic life, perhaps lacking nearby nutrient-rich upwelling currents; (2) an open ocean environment with aerobic bottom conditions that destroyed much of the organic matter; or (3) a rate of deposition that was either too slow, so that organic matter could be destroyed, or too rapid, so that organic matter was diluted by terrigenous sediments. Our sampling of this entire part of the early Tertiary section may be biased as our samples are concentrated on the San Nicolas platform, and sediments of similar age may exist, even including Late Cretaceous, that were deposited under conditions more favorable for organic growth and (or) preservation of such organic material. Eocene rocks are well exposed on the Channel Islands and San Nicolas Island and have high sandshale ratios and many conglomerate beds; much of the section is believed to have been deposited in a subsea fan environment. The basinward extension of these fans, where shale percentages would be higher, have probably not been sampled, and organic richness may be greater in these now-buried areas. However, the poor potential quality as measured is consistent with the low amount of hydrocarbons found in the onshore Paleogene sediments (348 million BOE, table 2) or the added oil in the Vaqueros Formation presumed to have been generated from the Paleogene (an additional 541 million BOE, table 2).

Within the Neogene section, the Miocene and in particular the middle to late Miocene shales have long been considered one of the most likely sources of the prolific oil production in the onshore coastal basins (Barbat, 1958; Philippi, 1965). Widespread sea-floor sampling of similar strata (fig. 8) supports previous interpretations on the extent of the Miocene seas and further indicates that good to excellent potential source rocks are present throughout the borderland (table 3 and tables 10 and 11). These samples also show a progressive increase in organic content from 3.2 percent in the early
Miocene to 6.8 percent in the late Miocene, with no apparent spatial preference throughout the outer basin area. Few Pliocene dart cores were obtained, and none have as yet been analyzed. If all other geologic factors were similar, the borderland should be as richly petroliferous as the onshore basins.

The Tertiary paleogeography and environmental conditions that controlled the organic content in the sediments are poorly known. However, the organic-rich Miocene sediments have an organic content not greatly different from the sediments now being deposited in the present basin floors (fig. 9). Emery (1960) states that the nearshore basin sediments have lower values than the offshore basins, and even lower values were obtained on the slope and very low values on the deep sea floor. "The peak concentration of organic matter at intermediate distance from the mainland is attributed to a very rapid rate of deposition of detrital sediments nearshore, resulting in the dilution or masking of organic matter there, and to a very slow rate of deposition far from shore, resulting in extensive oxidation of organic matter before it can become protected by burial. Thus the highest concentration occurs under optimum conditions of neither too rapid nor too slow a rate of deposition of detrital sediments" (Emery, 1960, p. 228). Recent sampling by the U.S. Geol. Survey gives low values (about 1 percent organic carbon) in the Holocene sediments on Cortes and Tanner Banks. Additional studies of other banks and ridges are continuing. If low values are found on the ridges, in contrast to higher values in the basins, this distribution of organic content might be used to infer paleobathymetry in Miocene samples of the same age.

\section{ORGANIC MATURITY}

Numerous methods have been proposed for determining the progressive transformation or metamorphism of organic matter into oil and gas (Bray and Evans, 1965; Philippi, 1965; Staplin, 1969; Gutjahr, 1966; Hood and others, 1975). The methods adopted by the U.S. Geol. Survey consist of quantitative and qualitative analyses of the insoluble and the extractable organic matter. The generation and the expulsion of petroleum from its source are relatively 


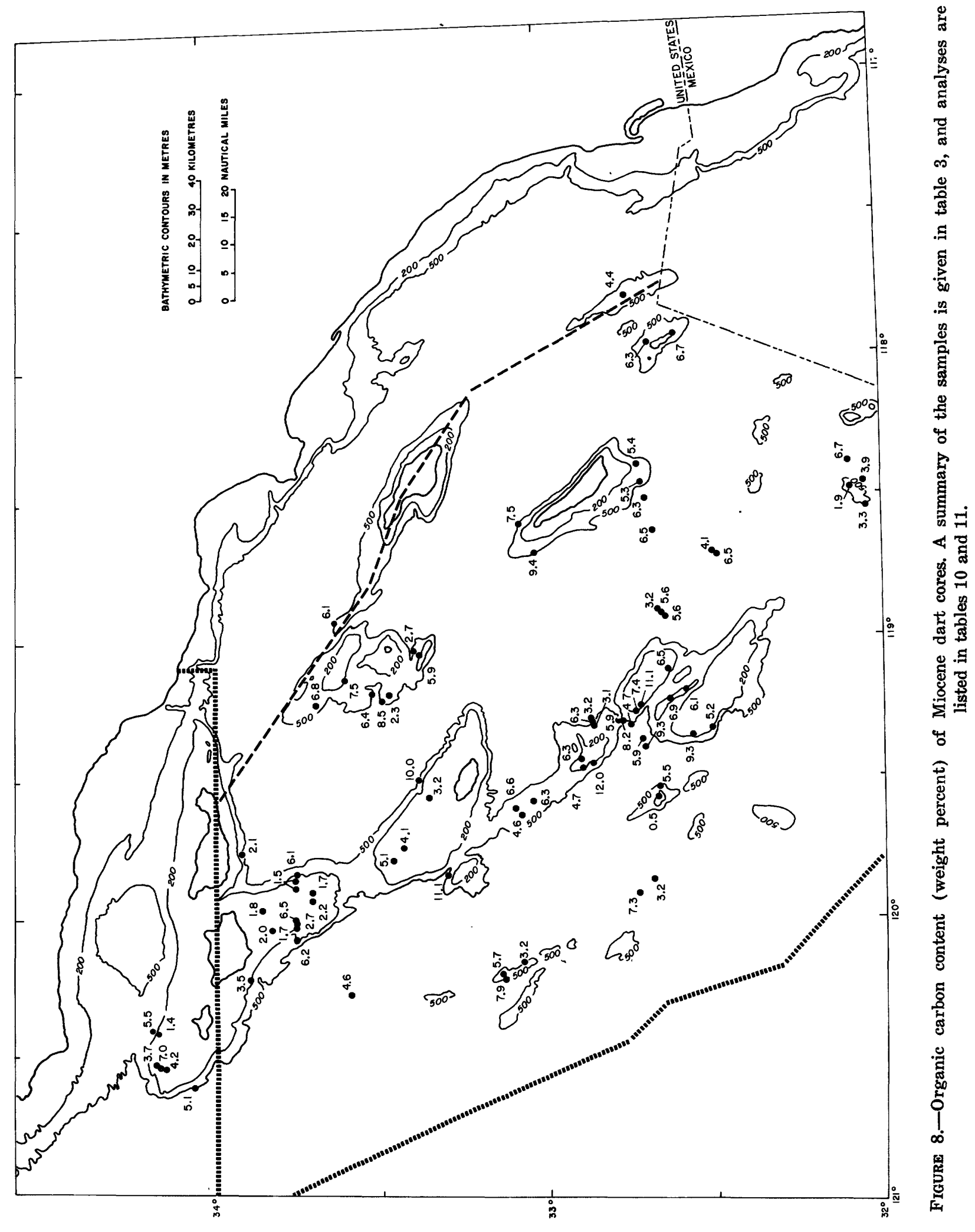




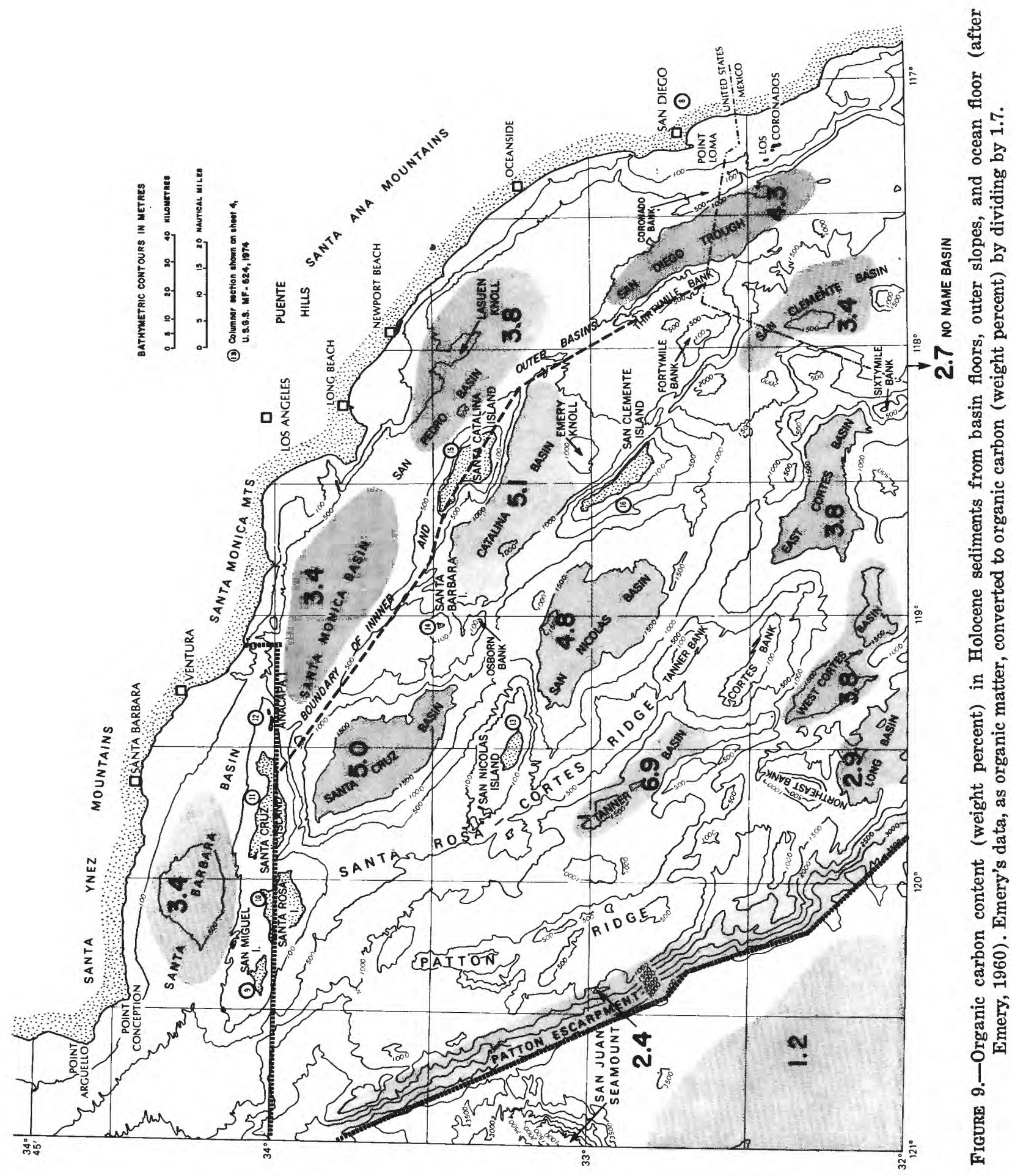


inefficient processes, and most of the organic matter remains in the rock, either as insoluble organic carbon or as soluble hydrocarbons. As petroleum is generated, the ratio of hydrocarbons to organic carbon increases to a point where $\mathrm{HC} / \mathrm{C}$ ratios greater than 1 percent (fig. 10) suggest mature potential source rocks. Other indicators of the stage of organic transformation are the characteristics of odd-even carbon number ratios of normal paraffins, the proportion of nonhydrocarbons in the extract, the ratio of saturated hydrocarbons to aromatics, and the elemental composition and depth of color of the remaining kerogen. Sufficient analyses were made with consistent results to generalize on the maturity of the Paleogene and
Neogene samples from the borderland, which has significant implications on the assessment of the petroleum potential of the area.

\section{ORGANIC MATURITY OF PALEOGENE AND NEOGENE SAMPLES}

All samples analyzed have a low hydrocarbon content, and their $\mathrm{HC} / \mathrm{C}$ ratios are all less than 1 percent required for good to excellent potential source rocks (fig. 10 ). The Paleogene rocks differ in some ways from the Neogene ones; saturated/aromatic hydrocarbon ratios in Paleogene rocks are greater than one, rather than less than one, and the $\mathrm{HC} / \mathrm{C}$ ratios are slightly higher. Although these might suggest a higher temperature history and hence a greater ma-

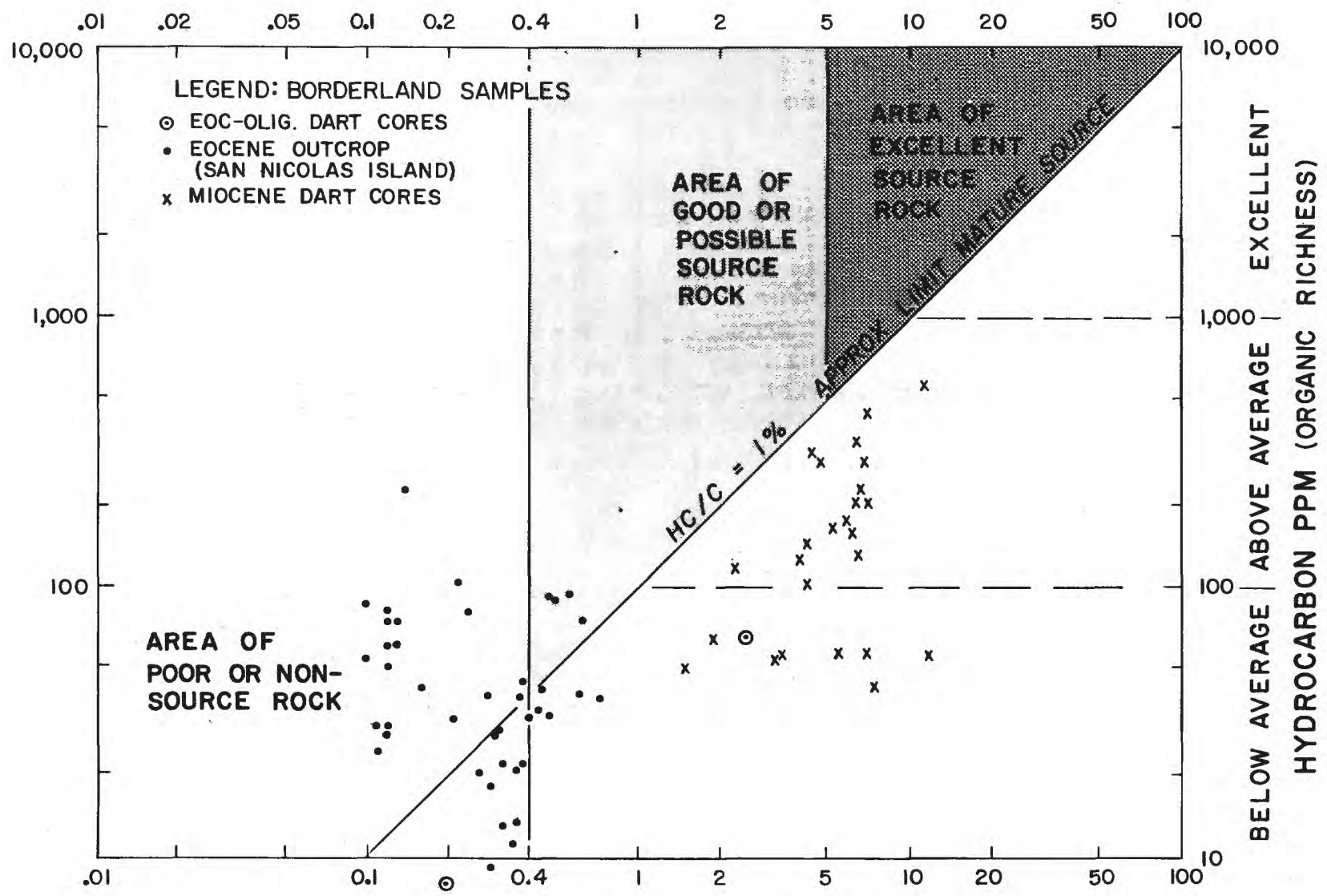

POOR OR NON-SOURCE ROCK $\rightarrow$ POPENTIAL SOURCE ROCK

ORGANIC CARBON WT. \%

FIGURE 10.-Source rock analysis chart with organic carbon content (weight percent) plotted against hydrocarbon ( $\mathrm{ppm}$ ) for Eocene-Oligocene and Miocene samples. Location of samples is shown on figures 7 and 8 . The organic carbon content (weight percent) of additional samples is listed in tables 10 and 11. 
turity, the chromatograms show a marked oddcarbon predominance, a characteristic of immaturity. It is likely that the Paleogene samples contain a different type of organic matter and may not have had a history of significantly deeper burial than the Miocene. Most Paleogene outcrop samples are judged immature and are interpreted not to have had a temperature history sufficiently high to generate petroleum.

Dart samples were obtained in areas of the borderland generally along banks and ridges in water depths less than $1,000 \mathrm{~m}$. In most of these areas, the sediments have been slightly tilted and subsequently beveled. Seismic profiles indicate that the Miocene sediments were covered by only a minimal amount of younger sediments. Supporting evidence is in the fresh samples themselves; the Paleogene are semiconsolidated and stiff to semibrittle, whereas the Neogene are only slightly consolidated, soft, plastic, and moldable between the fingers. X-rays of Miocene diatoms show no conversion from opal to cristobalite, additional confirmation of shallow burial (Bramlette, 1946; Murata and Nakata, 1974). Since the close of Miocene time, some basins have continued to subside relative to the uplifted banks and ridges, and the top of the Miocene is inferred to be as deep as 10,000 feet below sea level in several areas of the borderland (Vedder and others, 1974). Such subsidence and burial by as much as 7,000 feet of post-Miocene sediments have brought these excellent potential source rocks into a higher pressure and temperature regime than the sediments on the higher banks and ridges have experienced. By making various assumptions on the depth of burial, the paleogeothermal gradient, the conductivity of the sediments, effects of geologic time, and total overburden pressures, it is possible to postulate a temperature regime in the deeper parts of the present basins that is sufficient to generate hydrocarbons from these excellent potential Miocene source beds.

An early stage of organic diagenesis in a lower than normal thermal regime also may have occurred in these Miocene rocks. Six outcrop samples of the Monterey Formation from north of the Santa Barbara Channel between Point Conception and Gaviota were analyzed for comparison with Miocene dart core samples (table
10). George Claypool who analyzed these samples states (written commun., 1975) :

The organic geochemical characteristics of the Monterey at these localities are intermediate between that of the submarine outcrop samples, and the deeply buried Miocene rocks of the Los Angeles and Ventura basins. The Monterey samples from onshore have the same range of organic carbon content as the dart core samples, but contain significant higher extractable hydrocarbon contents, with $\mathrm{HC} / \mathrm{C}$ ratios of 1.5 percent and above. The composition of the extractable organic matter in the onshore Monterey is similar in many respects to that of the off shore Miocene dart core samples. Both have highly asphaltic extracts, and hydrocarbon fractions in which aromatics predominate over saturated hydrocarbons, and branched-cyclic saturates predominate over straight chain paraffins. These characteristics are consistent with thermal immaturity; however, it may be inore of a genetic characteristic of the organic matter deposited with Miocene rocks in California. One sample in particular (Wood-3-1) is 13.4 percent soluble in hot chloroform. This rock is exceptionally rich; if fracturing or some other favorable circumstances permitted, a heavy asphaltic oil might be produced from the Monterey at this locality. The significance of this comparison is that Miocene rocks of the California borderland may contain organic matter of a composition which yields a heavy oil at an early stage of diagenesis. This idea has recently been proposed by Powell, Cook, and McKirdy (1975) for phosphate-rich rocks in general, and in particular for Mohnian age source sediments in the Los Angeles basin.

Less is known about the Paleogene rocks of the borderland. Where sampled, the organic material they contain is immature, but the sampling has been concentrated on the San Nicolas platform, an area which is now high and may never have been deeply buried. Strata of the same age in other parts of the borderland, especially beneath the Miocene rocks in the deeper Santa Cruz and San Nicolas basins, could have encountered sufficiently high temperatures to generate hydrocarbons. The effect of time on the generation of hydrocarbons (Hunt, 1974; Connan, 1974) would have required a slightly lower temperature for the Paleogene than for the Miocene. The borderland may have had a higher than normal paleogeothermal gradient. Widespread volcanism probably began over much of the borderland toward the end of the Saucesian Stage, roughly 16 m.y. ago. Presumably this episode was preceded by a general rise in the geothermal gradient. Hawkins and Divis $(1975$, p. 323-324) have suggested from chemical evidence that the Miocene volcanic rocks on San Clemente and Santa Catalina Islands are 
the result of "mantle (plus sediment?) melting that may have been due to proximity of the paleo-East Pacific Rise rather than to an active subduction zone." Heat-flow measurements along the present East Pacific Rise are more than eight times normal, certainly sufficient to cause elevated temperatures in the overlying sedimentary column. Temperatures sufficient for generating hydrocarbons in the buried Eocene rocks seem plausible. The thickness of the buried Eocene section in these areas remains unknown, and the organic content of the sediments may be higher than that measured.

\section{POTENTIAL PETROLEUM RESERVOIR ROCKS PALEOGENE AGE}

The inferred distribution of Paleogene sediments throughout the borderland is shown in figure 7. These rocks apparently are absent elsewhere, as there is ample evidence that Neogene sediments lie on basement rocks to the east, west, and northeast of this broad Paleogene belt (Vedder and others, 1974). It is unclear whether this belt approximates the Paleogene marine basin, whether subsequent uplift and erosion limited its distribution, or whether large-scale lateral faults have displaced blocks and modified the original shape of the basin, as recently proposed (Howell and others, 1975). It is apparent that the Paleogene rocks contain abundant sandstone. Alluvial, shallow-marine to deepmarine sandstone occurs in the San Diego area. Deep-marine sandstone deposited by massgravity flow currents (Cole, 1975) was deposited on San Nicolas Island, and sediments deposited in environments ranging from bathyal to neritic are found on the Channel Islands (Doerner, 1969; Weaver and Doerner, 1969). Sandstone and conglomerate beds make up over 50 percent of the approximately $1,070+\mathrm{m}$ $(3,500 \mathrm{ft})$ of Paleogene section on San Nicolas Island, and in other areas sandstone sections $890 \mathrm{~m}(2,920 \mathrm{ft})$ thick have been measured, such as at Crook Point on San Miguel Island (Weaver and Doerner, 1969, p. 38). Throughout the Paleogene section there seems to be a sufficient quantity of coarse clastics for potential reservoirs. Compositionally, these sands have been derived from a predominantly continental terrane of siliceous plutonic rocks, quartz-rich metamorphic rocks containing mus- covite and epidote, and resistant metavolcanic rocks with an equigranular matrix of quartz and feldspar. These abundant, commonly thick sandstones with stable constituents ordinarily are excellent reservoir sands if sorting has been sufficient to remove the finer silt and clay size components and if deep burial, cementation, or porosity-destroying diagenesis did not occur later. In outcrop, and where sampled on the sea floor, these sandstones generally have moderate porosity, and in the subsurface they should have porosities equal to or better than the Eocene sandstones along the northern part of the Santa Barbara Channel, where maximum depth of burial has been much greater.

The fair reservoir quality of these sands would be improved with better sorting, which usually occurs in high-energy, shallow-water environments. Shallow-water sandstones have been noted in the Channel Islands and the San Diego area. To the north in the Santa Ynez Range and extending easterly into the Ventura basin, a gradual shallowing of the "Paleogene" basin in Oligocene time resulted in widespread shallow-water sands of the Alegria Formation and the nonmarine Sespe Formation. At the same time, a similar condition may have existed over much of the borderland or around its basinal margins. If it did exist, then good quality sands could be expected, and they might form the best potential reservoirs in the entire borderland. However, such sands have not been identified by the sampling or geophysical techniques available.

\section{NEOGENE AGE}

Miocene time began with a widespread marine transgression that deposited shallow-water sands of excellent reservoir quality over large parts of onshore southern California. In areas adjacent to the borderland, these sandstones are present in the Santa Barbara Channel eastward into the Ventura basin and, although absent in much of the Los Angeles basin, are present on the east side of that basin. Sandstones of early Miocene age occur on San Miguel and Santa Rosa Islands, are represented by coarse, nearsource breccias on Santa Cruz Island, are absent on Santa Catalina Island, and possibly are present beneath the middle Miocene volcanic 
rocks of Santa Barbara and San Clemente Islands. On the sea floor, Miocene sedimentary rocks rest either on Paleogene sandstones and fine-grained clastic rocks or directly on basement rocks. Dart core samples identified as early or middle Miocene are chiefly siltstone, mudstone, and marlstone. Sandstone typical of the onshore Vaqueros Formation is inferred to be present at places but has not been positively identified; it may be represented by undatable sandstone cores composed of well-sorted continental detritus, commonly containing broken fragments of neritic megafauna. Some of these sandstone samples also have clasts of intermediate to basic volcanic rocks, which are not found in the Paleogene sandstones but are common to the middle Miocene samples. Erosion and redeposition of Eocene sandstone and conglomerate during an early Neogene transgression could have resulted in widespread deposits of shallow-water, high-quality reservoir sands, but until more is known of the late Paleogene and early Neogene history and until data from core holes and future drilling become available, such conclusions will remain conjectural.

Over 80 percent of the total production from the onshore coastal basins has come from thick, extensive, deep-water upper Miocene and Pliocene sands in the Los Angeles and Ventura basins. These two rapidly subsiding basins derived the bulk of their coarse clastic material from nearby uplifted areas. In the borderland, basin geometry appears to have been well defined by early Pliocene time, and it is unlikely that deep-water sands could have been transported across the onshore and adjacent basins (Santa Barbara Channel, Santa Monica and San Pedro basins) in quantities great enough for sand accumulations of sufficient thicknesses for potential reservoirs. Data from each of these nearshore areas suggest that the lower Pliocene section (and deep-water sands) thin toward the borderland, that is, south across the Santa Barbara Channel (U.S. Geological Survey, 1974), west in fields along the Santa Monica coast, and southwest from the southern Los Angeles basin (California Division of Oil and Gas, 1974).

Miocene deep-water sands might be present at various localities in the outer basins but cannot be predicted with present data. Highlands existing during early and possibly into late Miocene time, such as "Catalinia" (Reed, 1951, p. 31) and those on Santa Cruz Island (McLean and others, 1975), did contribute coarse clastic material. However, these breccias, which crop out on Santa Cruz Island and along the coast south of the Los Angeles basin, must be much better sorted in the subsurface to be potential reservoirs.

It is encouraging that possible analogous sandstone reservoirs occur in the Santa Barbara Channel in both the lower and middle Miocene sections. Basal Monterey sands of Miocene age are present in the Santa Ynez Unit where a "sandy zone" thickens from $53 \mathrm{~m}$ (175 ft) at the west ( 4 to 5 miles south of Point Conception) to $305 \mathrm{~m}(1,000 \mathrm{ft}) 2 \theta$ miles east in the Hondo field (U.S. Geological Survey, 1974, p. II-137, 138), where they are productive along with the overlying fractured shale of the same age (p. II-163). A sandstone section of early Miocene age in the Rincon Formation is the main reservoir in the South Elwood offshore field (Dames and Moore, 1974 ; California Division of Oil and Gas, 1974); it is $47 \mathrm{~m}$ (155 ft) thick and occurs within a 305-m (1,000-ft)thick section of deep-water marine shale. Twelve miles to the west in the Hondo field, probable equivalent sandstone beds occur as three separate units totaling around 33 net $\mathrm{m}$ (100 net ft) of sand (U.S. Geological Survey, 1974, p. II-163).

The presence of these early and middle Miocene sandstone units could not be predicted even though there is an almost continuous exposure of correlative strata in the upturned and eroded flank of the Santa Ynez Mountains only 6 miles to the north that extends eastward from Point Conception for over 60 miles. In addition, hundreds of wells have been drilled onshore along this trend and numerous onshore as well as offshore wells in State waters have penetrated this same shale section, and none are known to have cut these sands.

If such sands are found in the borderland, they may add significantly to the hydrocarbon potential. The Monterey sands in the Hondo field underlie the fractured Monterey siliceous shale reservoir, which is "anticipated to contribute the major portion of the ultimate Monterey oil recovery" (U.S. Geological Survey, 
1974, p. II-151). The sands are "unconsolidated, very fine to medium sized, quartz sand grains" (p. II-153) with high porosities and permeabilities. Three tests in this reservoir indicate an initial daily rate estimated at 2,255 barrels of oil per day. Reserve estimates range from 94 million barrels by the American Petroleum Institute (Oil and Gas Journal, 1975b) for the Hondo field to 3 billion barrels by the National Petroleum Council (McCaslin, 1975) for the Santa Ynez Unit of which Hondo is the largest field. The Rincon sandstone reservoir in the South Elwood field is much smaller, and the ultimate production is estimated at less than 10 million barrels.

As reviewed in the onshore basins, the middle to late Miocene fractured siliceous shales are an important reservoir in areas such as Santa Maria basin and the newly discovered offshore fields in the Santa Ynez Unit of the Santa Barbara Channel. It seems reasonable, because of the widespread nature of the Miocene transgression over much of coastal California, that similar lithologies should exist and be potential reservoirs throughout the borderland. It is disappointing that dart cores of this age throughout the borderland are mainly fine-grained fossiliferous marlstone, mudstone, and siltstone that are not highly siliceous and do not appear comparable to the massive chert typical of the above proved reservoirs. This may be a sampling bias as a few chert lenses do occur in the diatomite sections on Santa Catalina and San Clemente Islands and diatoms are a common constituent in many Miocene dart cores. Volcanic detritus, especially glass shards, is common in some of the mudstone cores, but it is unlikely that diagenesis of these intermediate and basic volcanic sediments would transform them into dense cherts. It is conceivable that such sediments occur on the borderland, but they have not been identified. Structural reconstructions from seismic data suggest that during middle Miocene time the present basins were already subsiding more rapidly than the present ridges (at least the Santa Rosa-Cortes Ridge) (fig. 11). It is conceivable that more tuffaceous and siliceous sediments could have accumulated on the deeper flanks or in the basins.
An additional consideration is that onshore fractured shale reservoirs have difficult development problems. Erratic initial productive rates, common to many fields in the Santa Maria basin, are attributed to fracture porosity, resulting in many noneconomic wells. The overall moderate barrels-per-acre recoveries for these fields as noted in table 1 , have been obtained as a result of close well spacing. Such close spacing would be prohibitively expensive in an offshore field. Declines in production commonly are steep for the first few years, after which they stabilize at low rates. This characteristic for an offshore field would result in a long life but high operating cost.

\section{POTENTIAL PETROLEUM TRAPS}

The structural style of the borderland has been reviewed by others (Moore, 1969; Vedder and others, 1974; Junger, 1975). Studies on specific folds and faults are limited to smaller areas that are generally adjacent to the coast or islands (Jennings, 1973; Ziony and others, 1974 ; Campbell and others, 1975). Current U.S. Geol. Survey studies are in Santa Monica and San Pedro basins (Junger and Wagner, unpub data) and the shelf south of Santa Rosa Island and the Cortes and Tanner Banks (Greene, Clarke, and others, 1975).

Present knowledge indicates that fault patterns, types, ages, and displacements offshore are not significantly different from those onshore. Structural traps such as those associated with large-scale wrench faulting (Wilcox and others, 1973; Junger, 1975) are to be anticipated adjacent to such postulated strike-slip faults as the East Santa Cruz fault (Howell and others, 1974) and may result in the types of petroleum-bearing structures that have been so productive along the Newport-Inglewood trend of the Los Angeles basin (Harding, 1973).

Seismic profiles (Vedder and others, 1974, p. 9-10)

suggest that the major folds on the outer part of the borderland are very broad and nearly symmetrical in contrast to typical structures in the Ventura and Los Angeles basins, where tight, steep-limbed, asymmetric, en echelon folds are commonplace. Acoustic profiling records recently made across the northern part of the Santa Rosa-Cortes Ridge conirm the presence of a large anticlinal structure that is steeper on its western 


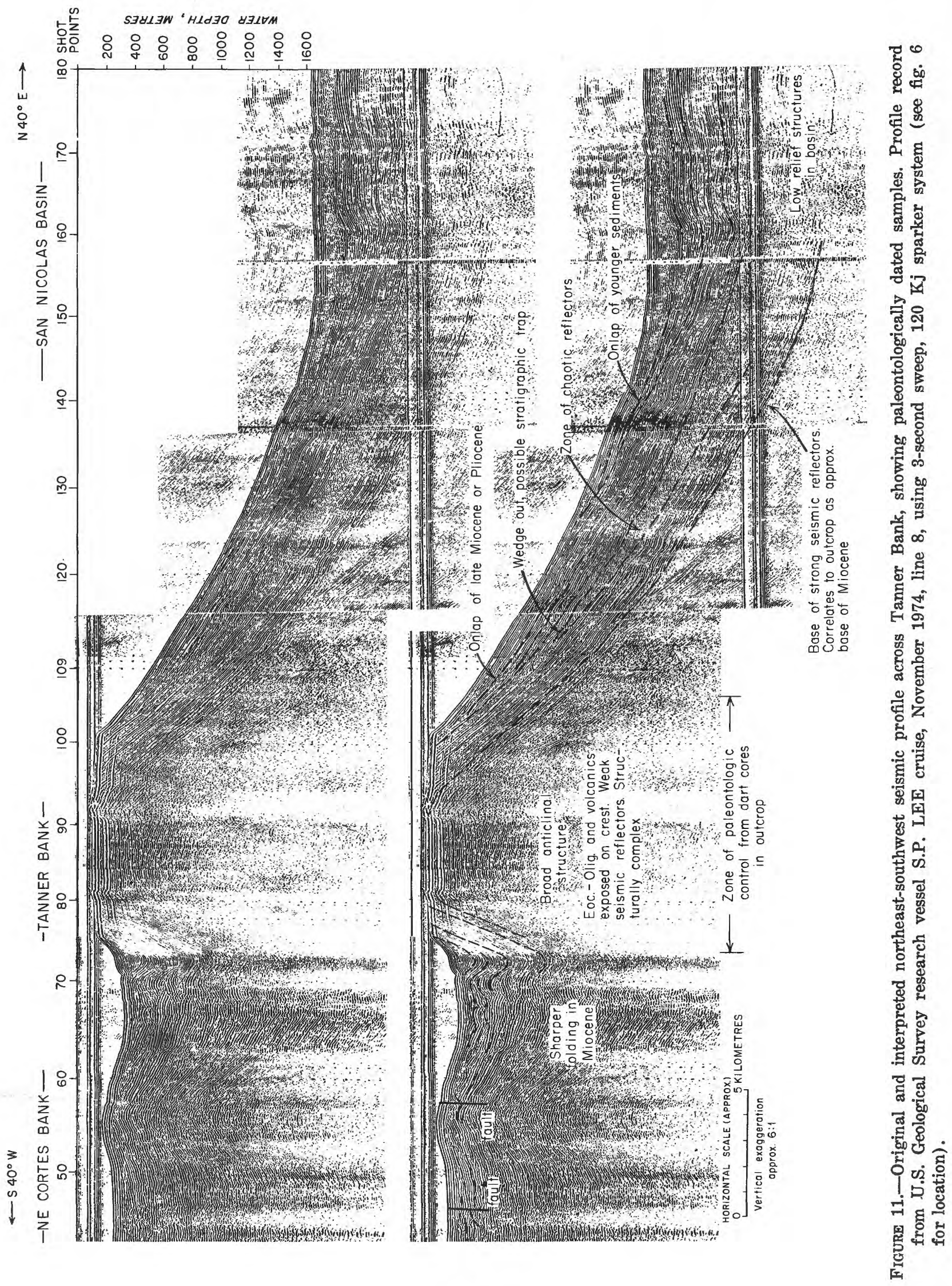


flank, but superimposed on it are numerous (smaller) discontinuous folds *** Many topographic highs seem to reflect underlying anticlinal structure *** Broad structural lows form both Santa Cruz *** and San Nicolas Basins ***, (but) both basins are flanked on their east and west margins by small northwest-trending low-amplitude folds that tend to die out basinward, although an upwarp is present in the central part of the San Nicolas Basin *** Tight folds and faults complicate the structural pattern on the east and west ends of the (Santa Monica) Basin. San Pedro Basin is more complex and seems to have undergone two discrete phases of evolution in late Miocene time followed by post-Miocene downfaulting at the northwest end and folding throughout.

Anticlinal folding, both on a large and small scale, as well as a favorable structural style associated with possible wrench faulting, shows that there are numerous structural prospects throughout the borderland. Many of the broad anticlinal structures that are in the shallower water depths in the outer basin area are eroded, exposing Paleogene strata along the crests (fig. 11). Some of the largest productive structures in the onshore basins (such as Ventura-Rincon trend) are related to the extraordinary subsidence (more than $7,600 \mathrm{~m} ; 25,000 \mathrm{ft}$ ) during late Neogene time and the rapid basin filling that was followed by post-late Pliocene deformation. Similar structures apparently are absent in the outer basins and do not seem to be well developed in the nearshore Santa Monica and San Pedro basins, a probable consequence of the much more subdued downwarping and only partial filling by post-Miocene sediments.

Prospective homoclinal traps with stratigraphic wedgeouts occur within the Miocene and younger section on many of the flanks of the major anticlinal ridges and banks where basinward thickening typically occurs. On the northeast flank of Tanner Bank the seismic character changes within the Miocene section, suggesting updip wedgeouts of a nonbedded section within a well-bedded sequence (fig. 11). The composition of the rocks that wedge out is unknown, as dart cores have recovered only Miocene mudstone updip on the erosional surface of the bank. The structural setting, age of sediments, and possible lithologic similarities are analogous to the Santa Maria Valley field in the Santa Maria basin.

Although much less can be interpreted seismically about the structures within the Paleo- gene rocks, the inferred structural complexity is greater than in Neogene rocks. Widespread Paleogene pinchouts are inferred in the deeper parts of the Santa Cruz and San Nicolas basins (fig. 7). These are believed to have formed by both eastward transgressive onlap and by truncation on the basis of surface mapping on Santa Cruz Island and interpretations of offshore seismic data (McLean and others, 1975; Junger, oral commun., 1975). This area is covered by thick marine Neogene shales, and there are obvious prospects where broad structures occur. Major obstacles to future production are the very deep water (about $1,000 \mathrm{~m} ; 3,280 \mathrm{ft}$ ) and possible absence of source rocks to charge these potential reservoirs.

\section{PETROLEUM RESOURCE ESTIMATES}

Since 1971, there have been several published estimates of undiscovered petroleum resources in the borderland. These estimates are widely divergent, but direct comparisons are impossible because some are quoted as oil-in-place whereas others are given in terms of recoverable resources. They all cover different areas, and one is limited to areas of less than $200 \mathrm{~m}$ water depth. These estimates are reviewed here because they are being widely quoted, and they are not compatible with recently acquired geologic data.

Most estimates are based on the work of Parker (1971), who presented a well-documented report of the assumptions, methods, and data used to arrive at his estimate of 75 billion barrels of oil-in-place (exclusive of presently producing offshore fields) for the $18,500 \mathrm{mi}^{2}$ (11.8 million acres) of the borderland. In his opinion, the values are a "fair estimate if the thickness and extent of the Pliocene and upper Miocene strata are as shown on the maps and sections. However, these critical factors are based on scanty information and liberal interpretations" (p. 191). These strata are now known to be much thinner and of more limited area than inferred by Parker, and he was unaware that older sediments were widely exposed over much of the truncated Santa Rosa-Cortes Ridge. The immaturity of potential source rocks was not known, and the presence of adequate reservoir sands was given little discussion. 
Parker's estimates were based largely on comparisons with the Los Angeles basin, a questionable premise in consideration of our present knowledge.

Using Parker's estimates, the Western Oil and Gas Association (WOGA) (1974, p. 11) concluded that "based on typical California recoveries (recoverable) reserves within the borderland included in the call for nomination (7.5 million acres) would be in the range of 6 to 19 billion barrels, with a gas/oil ratio of 2,000 cubic feet per barrel" with 14 billion barrels given as a reasonable estimate of potential production. After identification of the proposed lease sale area (from 7.5 million acres in the nomination area to $\mathbf{1 . 5 6}$ million acres in the sale area), WOGA recommended no changes in their estimate of 14 billion barrels, and the Bureau of Land Management used this figure as the high range of recoverable resources in their Draft Environmental Statement (1975, p. 3).

Hardoin (1975) of the California State Lands Commission estimated 80 billion barrels of oil-in-place for the entire borderland (12 million acres). He used the 75 billion barrels from Parker (1971) and included an additional 5 billion for the already discovered offshore fields (Venice, Torrance, Wilmington, Belmont offshore, Huntington Beach, and West Newport).

In 1974, the U.S. Geol. Survey made estimates for the Bureau of Land Management on the potential recoverable resources in each of the five main areas within the proposed lease area (1.56 million acres) which ranged from 1.6 to 2.7 billion barrels of oil (and 2.4 to 4.8 trillion $\mathrm{ft}^{3}$ of gas) (Bureau of Land Management, 1975, p. 1). Miller and others (1975), using additional geologic data and further study, reviewed the remaining resources for the entire continental United States and Alaska and the adjacent OCS areas in water depths to $200 \mathrm{~m}(656 \mathrm{ft})$. In their report, values for the borderland were not separated from the rest of the OCS area of California. Table 4 shows their estimates for the area in water deeper than $200 \mathrm{~m}$. These estimates, listed with the probabilities of 5 percent, 95 percent, and most likely as defined by Miller and others (1975), were made using many of the data discussed in the present re-
TABLE 4.-Estimated undiscovered recoverable oil resources, southern California borderland

[Values in billions of barrels of oil (Miller and others, 1975)]

\begin{tabular}{|c|c|c|c|c|c|}
\hline & & $\begin{array}{c}\text { Depth } \\
\text { (metres) }\end{array}$ & $\begin{array}{c}\text { Area } \\
\left.(\mathrm{mi})^{2}\right)\end{array}$ & $\begin{array}{c}\text { Esti- } \\
\text { mated } \\
\text { range }{ }^{1} \\
(95-5 \\
\text { percent) }\end{array}$ & $\begin{array}{c}\text { Statis- } \\
\text { tical } \\
\text { mean }\end{array}$ \\
\hline Inner & basin area -- & $\begin{array}{l}0-200 \\
>200\end{array}$ & $\begin{array}{r}940 \\
3,840 \\
4,780 \\
\end{array}$ & $\begin{array}{r}0.4-2.0 \\
.2-2.0\end{array}$ & $\begin{array}{r}1.01 \\
.81\end{array}$ \\
\hline Outer & basin area -- & $\begin{array}{l}0-200 \\
>200\end{array}$ & $\begin{array}{r}1,566 \\
16,183 \\
17,749 \\
\end{array}$ & $\begin{array}{ll}0 & -0.24 \\
0 & -1.6\end{array}$ & $\begin{array}{c}0.06 \\
.4\end{array}$ \\
\hline & $\begin{array}{l}\text { Total border- } \\
\text { land }\end{array}$ & $-\cdots$ & 22,529 & $\ldots$ & -- \\
\hline
\end{tabular}

1 The low value is the quantity associated with a 95 percent probability (19 in 20 chance) that there is at least this amount, and the higher value is at the 5 percent probability ( 1 in 20 chance).

port. Subsequent data, such as the organic chemistry analyses, have generally reinforced previous inferences bearing on the petroleum assessment, but several additional generalizations can be made. In depths less than $200 \mathrm{~m}$, the most favorable areas appear to be in the inner basin area along the coast in the Santa Monica and San Pedro Bays, even though considerable exploration has already been done there and elsewhere around the periphery of the Santa Monica and San Pedro basins. At these water depths in the outer basin area there is at least a $\mathbf{5}$ percent probability that no recoverable oil will be found.

In depths below $200 \mathrm{~m}$, potential resources at the 5 percent probability level are probably greater than shown in table 4 . However, the recovery of petroleum at these depths will be very expensive and dependent upon the existence of large accumulations. The more favorable areas in deeper waters are judged to be:

1. Where the middle Miocene is at maximum or near maximum depth of burial.

2. In structural and stratigraphic traps on the flanks of major uplifts such as Tanner Bank.

3. In the vicinity of suspected large-scale lateral faulting where structures may be similar to those along the Newport-Inglewood trend.

4. Where pre-Miocene sediments are thickest and most deeply buried, and where shale predominates and may be richer in organic matter than so far measured.

5. In inferred shallow-marine sands of Oligocene or early Miocene age, structurally positioned to receive oil generated either 
from the younger organic-rich Miocene sediments or from questionably inferred source rocks of older age.

No revised estimates have been made on the basis of these new data, for they are beyond the scope of this paper. As indicated, new data affect interpretations and the resulting assessment of the petroleum potential, but as of now, such data are not sufficient to alter the existing estimates substantially.

\section{CONCLUSIONS}

The southern California borderland, with its structural and sedimentary basins, is a part of the much larger Pacific plate margin which includes all the onshore oil-producing basins west of the San Andreas fault. An assessment of the petroleum potential of this frontier area is aided by comparing it with the similar, wellexplored oil-producing region.

The cumulative production in California (to January 1,1975 ) amounted to 21,190 million barrels of oil (plus gas as barrels of oil equivalent), and the remaining demonstrated reserves (proved and indicated) from known fields are currently estimated to be 5,775 million barrels of oil (plus gas as BOE). Over half of this production (11,852 million barrels) has come from five coastal basins; Los Angeles, Ventura, Santa Maria, Cuyama, and Salinas. The petroleum is unevenly distributed between these basins, as well as by stratigraphic age of the reservoir, by field size, and reservoir rock type. Los Angeles and Ventura basins account for 88 percent of the total oil produced. Of the 212 fields in these coastal basins, 52 percent of the oil has come from the five largest fields, and 87 percent of production has come from late Miocene and younger reservoirs with only 0.2 percent from Eocene and Cretaceous rocks. Over 80 percent is in reservoirs of thick deep-marine sands, and major accumulations in the Los Angeles and Ventura basins typically have net sand thicknesses exceeding $328 \mathrm{~m}$ (1,000 ft). Shallowmarine sands of excellent reservoir quality make up 10 percent of the reservoirs, and these are concentrated in the Salinas, Cuyama, and western Ventura basins. A minor but little understood reservoir is the fractured shale of the Miocene Monterey Formation. Nearly 5 percent of all production in these coastal basins (552 million barrels) has come from this formation in the Santa Maria basin, but recent discoveries and planned production in the Santa Barbara Channel may markedly increase the percentage derived from this reservoir rock type.

In the 59 fields with production over 20 million barrels, the dominant trap type is the faulted anticline. Most of the fields larger than 100 million barrels have recoveries exceeding 100,000 barrels per acre, and two are as high as 500,000 barrels per acre. Recoveries in fields smaller than 50 million barrels are generally less than 50,000 barrels per acre.

If large accumulations similar to those onshore are to be found offshore, they will be in deep basins filled or partly filled with late Tertiary sediments, in thick buildups of deep marine turbidites, and in anticlinal structures. The petroleum presumably will have moderate oil gravity sufficient to ensure high per well recoveries. Large dry gas fields are not expected to be present. Smaller oil accumulations can be expected from shallow-water sands, probably of Oligocene or early Miocene age, and from fractured shale of the widespread Miocene Monterey Formation.

Many of the major requirements necessary for these large accumulations of petroleum are missing in the offshore region. The total sedimentary section is thin, and many banks and ridges have been truncated to expose early Tertiary rocks. Miocene strata rest directly on basement in large areas offshore. Early Tertiary rocks are present along Santa Rosa-Cortes Ridge but are much thinner than correlative strata onshore to the northeast. Thick turbidite sands equivalent to those in the onshore producing Los Angeles and Ventura basins are not expected to be present in any of the basins seaward of Santa Catalina Island. In addition, the nearshore Santa Monica and San Pedro Bays, which are the most favorable prospective areas, have yielded discouraging results from previous stratigraphic tests. Organic geochemical analyses reveal that the strata of Miocene age are very good to excellent potential source rocks and are comparable to those onshore that are the source for the large volumes of oil in the middle Miocene and younger reservoirs. The 
early Tertiary samples, however, have insufficient organic matter to be considered as potential source rocks. Sampling on the ridges and banks indicates little depth of burial for the entire Tertiary section. The organic matter is immature, indicating little burial and a thermal regime insufficient for the generation of petroleum. Although seeps are common onshore and in the Santa Barbara Channel, no documented oil or gas seeps have been reported seaward of the Channel Islands. Only 11 percent of the borderland is in water less than $200 \mathrm{~m} \mathrm{(660}$ ft) deep, a factor that should be considered from a practical and economic standpoint.

The positive aspects for petroleum occurrence on the borderland include the high organic content of the Miocene section. In the more deeply buried areas of the borderland, these strata could be excellent source rocks, and there is some evidence that temperature histories need not be as high as previously deduced for the generation of asphaltic oil from this type of organic shale. Fractured shale reservoirs both in the deeper basins and on the down-flank margins of major uplifts are prospective areas for significant accumulations. Structural traps, although generally not having dips as steep as those onshore, are present throughout the borderland. Because the early Tertiary depositional history is as yet little understood, large areas of the borderland may contain shallow-water sands of excellent reservoir quality, particularly those laid down in Oligocene and early Miocene time prior to the major Miocene transgression. The distribution, thickness, and character of Late Cretaceous and Paleocene rocks are poorly known and are not considered. The areal distribution of dart cores that recovered Eocene sediments is limited, and this sampling bias may have overlooked potential Eocene or older source rocks that could have charged these inferred reservoirs.

Previous estimates on the petroleum potential are not compatible with all the known geologic facts. Although there are many gaps in our knowledge of this area, it is unlikely that additional geologic data will vary so greatly as to justify any marked increase in the estimates already published by the U.S. Geol. Survey (Miller and others, 1975). Additional data will, however, more closely delineate prospective areas for possible exploratory drilling. The most favorable areas for significant accumulations are those in deep water.

\section{REFERENCES CITED}

American Petroleum Institute, 1975, Reserves of crude oil, natural gas liquids, and natural gas in the United States and Canada and the United States productive capacity as of December 31, 1974: Am. Petroleum Inst., v. 29, May 1975, 254 p.

Bailey, T. L., 1947, Origin and migration of oil into Sespe redbeds, California: Am. Assoc. Petroleum Geologists Bull., v. 31, no. 11, p. 1913-1935.

Eaker, C. R., 1972, Organic geochemistry and geological interpretations: Jour. Geol. Education, Oct. 1972, p. 221-234.

Baldwin, T. A., 1971, Petroleum potential of California central Coast Ranges, in Cram, I. H., ed., Future patroleum provinces of the United States-their geology and potential: Am. Assoc. Petroleum Geologists Mem. 15, p. 309-315.

Barbat, W. F., 1958, The Los Angeles basin area, California, in Higgins, J. W., ed., A guide to the geology and oil fields of the Los Angeles and Ventura regions (California) : Am. Assoc. Petroleum Geologists and Soc. Econ. Paleontologists and Mineralogists, Pacific Secs., p. 37-49; in Weeks, L. G., ed., Habitat of oil -a symposium: Tulsa, Okla., Am. Assoc. Petroleum Geologists, p. 62-77.

Beyer, L. A., Sasnett, N. B., Pisciotto, K. A., 1975, Interpretation of gravity and magnetic surveys of the California continental borderland (abs.) : Am. Assoc. Petroleum Geologists Pacific Sec. Mtg., Long Beach, Aprl 23-26, 1975, p. 8.

Bramlette, M. N., 1946, The Monterey Formation of California and the origin of its siliceous rocks: U.S. Geol. Survey Frof. Paper 212, p. 567-560.

Bray, E. E., and Evans, E. D., 1965, Hydrocarbons in the non-reservoir rock source beds: Am. Assoc. Petroleum Geologists Bull., v. 49, p. 248-257.

Bureau of Land Management, 1975, Proposed 1975 outer continental shelf, oil and gas general lease sale, offshore southern California, OCS Sale No. 35: Draft Environmental Statement, Washington, D.C., U.S. Govt. Printing Office, DES 75-8, v. 1-4, variously paged.

California Division of Oil and Gas, 1974, California oil and gas fields; south, central coastal and offshore California, v. 2: California Div. Oil and Gas Rept. TR 12.

1975, 60th annual report of the State oil and gas supervisor: California Div. Oil and Gas Rept. PRO6, $175 \mathrm{p}$.

Campbell, R. H., Wolf, S. C., Hunter, R. E., Wagner, H. C., Junger, A. and Vedder, J. G., 1975, Geologic map and sections, Santa Barbara Channel region, California: U.S. Geol. Survey open-file map 75-123. 
Clarke, S. H., and Nilsen, T. H., 1973, Displacement of Eocene strata and implications for the history of offset along the San Andreas Fault, central and northern California, in Kovach, R. L., and Nur, A., eds., Proceedings of the conference on tectonic problems of the San Andreas fault system: Stanford Univ. Pubs. Geol. Sci., v. XIII, p. 358-367.

Cole, M. R., 1975, Eocene sedimentation and paleocurrents, San Nicolas Island, California: Geol. Soc. Anserica Ann. Mtg., Cordilleran Section, Guidebook 3, March 1975, 32 p.

Connan, J., 1974, Time-temperature relation in oil genesis: Am. Assoc. Petroleum Geologists Bull., v. 58, p. 2516-2521.

Conservation Committee of California Oil Producers, 1975, Annual review of California oil and gas production, 1974: Los Angeles, Conserv. Comm. Calif. Oil Producers, $293 \mathrm{p}$.

Crawford, F. D., 1971, Petroleum potential of Santa Maria province, California, in Cram, I. H., ed., Future petroleum provinces of the United Statestheir geology and potential: Am. Assoc. Petroleum Geologists Mem. 15, p. 316-328.

Curran, J. F., Hall, K. B., and Herron, R. F., 1971, Geology, oil fields, and future petroleum potential of Santa Barbara Channel area, California, in Cram, I. H., ed., Future petroleum provinces of the United States-their geology and potential: Am. Assoc. Petroleum Geologists Mem. 15, p. 192-211.

Dames and Mnore, 1974, Resumption of drilling operations in the South Ellwood offshore oil field from platform Holly, final environmental impact report: California State Lands Comm., 3 vols., 1561 p.

Dickinson, W. R. 1969, Geologic problems in the mountains between Ventura and Cuyama, in Guidebook, Upper Sespe Creek: Soc. Econ. Paleontologists and Mineralogists, Pacific Sec., Oct. 17-18, 1969.

Doerner, D. P., 1969, Lower Tertiary biostratigraphy of southwestern Santa Cruz Island, in Weaver, D. W., Geology of the northern Channel Islands: Am. Assoc. Petroleum Geologists and Soc. Econ. Paleontologists and Mineralogists, Pacific Sec., Spec. Pub. p. 17-29.

Emery, K. P., 1960, The sea off southern California, a modern hahitat of petroleum: New York, N.Y., John Wiley and Sons, Inc., $366 \mathrm{p}$.

Fischer, P. J., and Stevenson, A. J., 1973, Natural hydrocarbon seeps along the northern shelf of the Santa Barbara basin, California, in Santa Barbara Channel Region Revisited: Am. Assoc. Petroleum Geologists Guidebook Trip 3.

Frame, R. G., 1960, California offshore petroleum development: California Div. Oil and Gas, Summary of Operations, v. 46 , no. 2, p. 5-46.

Gardett, P. H.. 1971, Petroleum potential of Los Angeles basin, California, in Cram, I. H., ed., Future petroleum provinces of the United States-their geology and potential: Am. Assoc. Petroleum Geologists Men. 15, p. 298-308.

Greene, H. G., Clarke, S. H., Field, M. E., Wagner, H. C., and Linker, F., 1975, Preliminary open-file report on the environmental geology of parts of the southern California continental borderland: U.S. Geol. Survey open-file rept. 75-596.

Greene, H. G., Silver, E., and von Huene, R., 1975 Seismic reflection profiles, USNS BARTLETT, Nov. 1972 cruise, offshore central and southern California : U.S. Geol. Survey open-file rept. 75-121.

Gutjahr, C. C. M., 1966, Carbonization of pollen grains and spores and their application: Leidse Geol. Meded., v. 38, p. 1-30.

Halboùty, M. T., Meyerhoff, A. A., King, R. E., Dott, Jr., R. H., Klemme, H. D., and Shabad, T., 1970, World's giant oil and gas fields, geologic factors affecting their formation and basin classification, in Halbouty, M. T., ed., Geology of giant petroleum fields: Am. Assoc. Petroleum Geologists Mem. 14, p. 502-556.

Harding, T. P., 1973, Newport-Inglewood trend, California-an example of wręnching style of deformation: Am. Assoc. Petroleum Geologists Bull., v. 57, no. 1, p. 97-116.

Hardoin, J. L., 1975, Public opinion will govern California's offshore future: World Oil, Aug. 1, 1975, p. 50-59.

Haun, J. D., ed., 1975, Methods of estimating the volume of undiscovered oil and gas resources: Am. Assoc. Petroleum Geologists, Studies in Geology, no. 1.

Hawkins, J. W., and Divis, A. E., 1975, Petrology and geochemistry of mid-Miocene volcanism of San Clemente and Santa Catalina Islands and adjacent areas of southern California borderland (abs.): Geol. Soc. America Abs. with Programs, Cordilleran Sec. Mtg., Calif. State Univ., Los Angeles, March 25-27, 1975, p. 323-324.

Hileman, J. A., Allen, C. R., and Nordquist, J. M., 1973, Seismicity of the southern California region, 1 January 1972 to 31 December 1972 : Californ'a Inst. Technology Seismological Lab. Contr. 2385, 487 p.

Hood, A., Gutiahr, C. C. M., and Heacock, R. L., 1975, Organic metamorphism and the generation of petroleum: Am. Assoc. Petroleum Geologists Bull., v. 59 , no. 6 , p. $986-996$.

Howell, D. G., 1975, Middle Eocene paleogeography of southern California, in Future energy horizons of the Pacific coast, Paleocene Symposium and selected technical papers: Am. Assoc. Petroleum Geologists, Soc. Econ. Paleontologists and Mineralogists, Ann. Mtg., Long Beach, Calif., p. 272-293.

Howell, D. G., Stuart, C. J., Platt, J. P., and Hill, D. J., 1974, Possible stripe-slip faulting in the southern California borderland: Geology, v. 2, no. 2, p. 93-98.

Hunt, J. M., 1974, How deep can we find economic oil and gas accumulations: Soc. Petroleum Engineers Paper SPE 5177, 4 p., 7 figs.

Jennings, C. W., 1973, State of California preliminary fault and geologic map: California Div. Mines and Geology Prelim. Rept. 13, scale 1: 750,000.

Junger, Arne, 1975, Some thoughts on the structure of the continental borderland, southern California (abs.) : Geol. Soc. America Abs. with Programs, Cordilleran Sec., March 25-27, 1975, p. 52-53. 
Kennedy, M. P., and Moore, G. W., 1971, Stratigraphic relations of Upper Cretaceous and Eocene formation, San Diego, coastal area, California: Am. Assoc. Petroleum Geologists Bull., v. 55, p. 709-722.

McCaslin, John, 1975, World offshore production, reserves listed by fields: Oil and Gas Journal, May 1975, p. 226-232.

McFarland, L. C., and Greutert, R. H., 1971, Los Angeles basin: World's most prolific-for its size: Oil and Gas Journal, August 16, 1971, p. 112-115.

McLean, H., Howell, D. G., and Vedder, J. G., 1975, Paleogeographic implications of the Miocene basement unconformity, Santa Cruz Island, California (abs.): Geol. Soc. America Abs. with Programs, Cordilleran Sec. Mtg., Calif. State Univ., Los Angeles, March 25-27, 1975, p. 346.

McNabb, D., 1975, Deep water-drilling drive gains momentum in gulf: Oil and Gas Journal, Sept. 8, 1975, p. 17-20.

Miller, B. M., Thomsen, H. L., Dolton G. L., Coury, A. B., Hendricks, T. A., Lennartz, F. E., Powers, R. B., Sable, E. G., Varnes, K. L., 1975, Geological estimates of undiscovered recoverable oil and gas resources in the United States: U.S. Geol. Survey Circ. 725,78 p.

Moody, J. D., Mooney, J. W., Spivak, J., 1970, Giant oil fields of North America, in Halbouty, M. T., ed., Geology of giant petroleum fields: Am. Assoc. Petroleum Geologists Mem. 14, p. 8-17.

Moore, D. G., 1969, Reflection profiling studies of the California continental borderland-structure and Quaternary turbidite basins: Geol. Soc. America Spec. Paper 107, 142 p.

Moore, G. W., and Beyer, L. A., 1975, Seismic reflection profiles R/V KELEZ Nov.-Dec. 1973, continental borderland of southern California: U.S. Geol. Survey open-file rept. $75-330$.

Moore, G. W., and McCulloch, D. S., 1975, Acoustic reflection profiles M/V OIL CITY, June 1969, offshore southern California: U.S. Geol. Survey open-file rept. $75-347$.

Munger, A. H., ed., 1974, State and federal exploratory wells and core holes drilled off the west coast of continental U.S.A. prior to 1974: Munger Oilogram, Los Angeles, Calif.

Murata, K. J., and Nakata, J. K., 1974, Cristobalite stage in the diagenesis of diatomaceous shale: Science 184, p. 567-568.

Nagle, H. E., and Parker, E. S., 1971, Future oil and gas potential of onshore Ventura basin, California, in Cram, I. H., ed., Future Petroleum provinces of the United States-their geology and potential: Am. Assoc. Petroleum Geologist Mem. 15, v. 1, p. 254297.

Nilsen, T. H., and Clarke, S. H., Jr., 1975, Sedimentation and tectonics in the early Tertiary continental borderland of central California: U.S. Geol. Survey Prof. Paper 925, 64 p.
Oil and Gas Journal, 1975a, Here are the big U.S. reserves: Oil and Gas Journal, January 27, 1975, p. 116-118.

_—_ $1975 \mathrm{~b}, \mathrm{API}$ and AGA reveal reserves, productive capacity of big U.S. Fields: Oil and Gas Journal, April 21, 1975, p. 40-41.

Parker, F. S., 1971, Petroleum potential of southern California offshore, in Cram, I. H., ed., Future petrol um provinces of the United States-their geology and potential: An. Assoc. Petroleum Geologists Mem. 15, v. 1, p. 178-191.

Philippi, G. T., 1957, Identification of oil-source beds by chemical means: International Geologic Congress, 20th Mexico, 1956, Sec. 3, p. 25-38.

-1965 , On the depth, time and mechanism of petroleum generation: Geochim. et Cosmochim. Acta 1965, v. 29, p. 1021-1049.

Powell, T. G., Cook, P. J., and McKirdy, D. M., 1975, Organic geochemistry of phosphorites: Relevance to petroleum genesis: Am. Assoc. Petroleum Geologists Bull., v. 59, p. 618-632.

Pussey, W. C., III, 1973, How to evaluate potential oil and gas source rocks: World Oil, April 1973, p. 71-75.

Redwine, L. E., 1955, A review of the geology and oil operations, Santa Barbara Channel Islands, under. Coast Geological Society Meetings: Am. Assoc. Petroleum Geologists, Pacific Petroleum Geologists, Pacific Sec. Newsletter, v. 9, no. 2, 1955.

Reed, R. D., 1951, Geology of California: Tulsa, Okla. Am. Assoc. Petroleum Geologists, 355 p.

Roberts, A. E., 1975, Selected geologic literature on the California continental borderland and adjacent areas: U.S. Geol. Survey Circ. 714, 116 p.

Ronov, A. B., 1958, Organic carbon in sedimentary rocks (in relation to the presence of petroleum): Geochemistry, no. 5, p. 510-536 (translated from Russian Geokhimiya).

Shepard, F. P., and Emery, K. O., 1941, Submarine topography off the California coast-canyons and tectonic interpretation: Geol. Soc. America Spec. Paper 31, 171 p.

Staplin, F. L., 1969, Sedimentary organic matter, organic metamorphism, and oil and gas oscurrence: Bull. Canadian Petroleum Geology, v. 17, no. 1, p. 47-67.

Truex, J. N., 1972, Fractured shale and basement reservoir, Long Beach unit, California: Am. Assoc. Petroleum Geologists Bull., v. 56, no. 10, p. 1931-1938.

U.S. Geological Survey, 1974, Proposed plan of development, Santa Ynez Unit, Santa Barbara Channel, off California-final environmental statement: U.S. Geol. Survey FES 74-20, v. 1-3, variously paged.

Vedder, J. G., 1968, Stratigraphy of central San Rafael Mountains, Santa Barbara County, California (abs) : Geol. Soc. America Spec. Paper 115, p. 358. 1975, Acoustic reflection profiles, R/V KELEZ May-June 1973, Leg 3 offshore southern California: U.S. Geol. Survey open-file rept. 75-265. 
Vedder, J. G., Beyer, L. A., Jungar, A. Moore, G. W., Roberts, A. E., Taylor, J. C., and Wagner, H. C., 1974 , Preliminary report on the geology of the continental borderland of southern California: U.S. Geol. Survey Misc. Field Studies Maps MF-624, 34 p., 9 sheets.

Vedder, J. G., and Norris, R. M., 1963, Geology of San Nicolas Island, California: U.S. Geol. Survey Prof. Paper 369, 65 p.

Vedder, J. G., Taylor, J. C., Arnal, R. E., Bukry, J. D., 1976, Maps showing location of selected pre-quaternary rock samples from the California continental borderland: A supplement to samples described in Vedder and others (1974) : U.S. Geol. Survay Misc. Field Studies Maps MF-737, 3 maps.

Vedder, J. G., Wagner, H. C., and Schoellhamer, J. E., 1969, Geologic framework of the Santa Barbara Channel region, in Geology, petroleum development, and seismicity of the Santa Barbara Channel region, California: U.S. Geol. Survey Prof. Paper 679-A, $11 \mathrm{p}$.

Wagner, H. C., 1975, Seismic reflection profiles, $\mathrm{R} / \mathrm{V}$ KELEZ May 1973, Leg 2, offshore southern California: U.S. Geol. Survey open-file rept. 75-205.

Weaver, D. W., and Doermer, D. P., 1969, Lower Tertiary stratigraphy, San Miguel and Santa Rosa Islands, in Weaver, D. W., ed., Geology of the northern Channel Islands: Am. Assoc. Petroleum Geologists and Soc. Econ. Paleontologists and Mineralogists, Pacific Sec., Spec. Pub., p. 30-47.

Weaver, D. W., Doerner, D. P., and Nolf, Bruce, 1969, Geology of the northern Channel Islands (California): Am. Assoc. Petroleum Geologists and Soc. Econ. Paleontologists and Mineralog:sts, Pacific Sec., Spec. Pub., 200 p.
Weeks, L. G., 1975, Potential petroleum resourcesclassification, estimation, and status, in Haun, J. D., ed., Methods of estimating the volume of undiscovered oil and gas resources: Am. Assoc. Petroleum Geologists, Studies in Geology, no. 1, p. 31-49.

Western Oil and Gas, 1974, Environmental assessment study, proposed sale of Federal oil and gas leases, southern California outer continental shelf: Los Angeles, Dames and Moore, 3 vol.

Wilcox, R. E., Harding, T. P., and Seely, D. R., 1973, Basin wrench tectonics: Am. Assoc. Petroleum Geologists Bull., v. 57, no. 1, p. 74-96.

Wilkinson, E. R., 1971, California offshore oil and gas seeps: California Div. Oil and Gas, California Oil Fields-Summ. of Operations, v. 57, no. 1, p. 5-28. 1972, California off shore oil and gas seeps: California Div. Oil and Gas, 11 p.

Williams, J. A., 1974, Characterization of oil types in Willeston Basin: Am. Assoc. Petroleum Geologists Bull., v. 58, no. 7, p. 1243-1252.

Wilson, H. M., 1975, Offshore California, long shut down, begins to stir: Oil and Gas Journal, July 7, 1975 , p. 15-19.

Wolf, S. C., 1975, Seismic reflection profiles R/V POLARIS, March 1972 offshore southern California, Pt. Conception cruise: U.S. Geol. Survey open-file rept. 75-166.

Yerkes, R. F., McCulloh, T. H., Schoellhamer, J. E., and Vedder, J. G., 1965, Geology of the Los Angeles basin, California-an introduction: U.S. Geol. Survey Prof. Paper 420-A, 57 p.

Ziony, J. I., Wentworth, C. M., Buchanan, J. M., and Wagner, H. C., 1974, Preliminary map showing recency of faulting in coastal southern California: U.S. Geol. Survey Misc. Geol. Inv. Map I-585. 
TABLES 5-11 

TABLE 5.-Major fields: Los Angeles basin

[Ranked-by cumulative oil plus $\mathrm{BOE}^{1}$ to January 1,1975 ]

\begin{tabular}{|c|c|c|c|c|c|c|}
\hline Field & $\begin{array}{l}\text { Cumu- } \\
\text { lative } \\
\text { oil } \\
\text { (thou- } \\
\text { sands of } \\
\text { barrels) }\end{array}$ & $\begin{array}{l}\text { Cumu- } \\
\text { lative } \\
\text { oil t } \\
\text { gas as } \\
\text { BOE }\end{array}$ & $\begin{array}{c}\text { Percent } \\
\text { of } \\
\text { total }\end{array}$ & $\begin{array}{c}\text { Cumu- } \\
\text { lative } \\
\text { percent } \\
\text { of basin } \\
\text { tetal }\end{array}$ & $\begin{array}{c}\text { Maxi- } \\
\text { mum } \\
\text { proved } \\
\text { acreage }\end{array}$ & 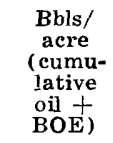 \\
\hline Wilmington " & $1,681,737$ & $1,843,544$ & 23.5 & 23.5 & 14,500 & 127,141 \\
\hline Long Beach & 878,214 & $1,060,297$ & 13.5 & 37 & 1,815 & 584,185 \\
\hline Huntington Beach & 923792 & 1.053 .719 & 13.4 & 50.4 & 6,290 & 167,523 \\
\hline Santa Fe Springs & 600,694 & 740,971 & 9.4 & 59.8 & 1,480 & 500,656 \\
\hline Dominquez & 258,309 & 321,239 & 4.1 & 73.5 & 1,670 & 192,359 \\
\hline Coyete West & 232,151 & 264,438 & 3.4 & 76.9 & 1,125 & 234,056 \\
\hline Seal Beach & 188,000 & 221,735 & 2.8 & 79.7 & 870 & 254,868 \\
\hline Montebello & 184,506 & 219,894 & 2.7 & 82.4 & 1,600 & 127.434 \\
\hline Torrance & 182,294 & 203,106 & 2.6 & 85.0 & 7,273 & 27,926 \\
\hline Richfield & 164,863 & 193,561 & 2.5 & 87.5 & 1,600 & 120,976 \\
\hline Rosecrans & 89,828 & 122,943 & 1.6 & 89.1 & 725 & 169,577 \\
\hline
\end{tabular}

${ }^{1} \mathrm{BOE}=$ Barrels oil equivalent of gas at $6.000 \mathrm{ft}^{3}=1$ bbl oil (approx BTU equivalent).

2 Wilmington field is treated separately here, but in table 1 the Wilmington trend includes Wilmington, Torrance, and Belmont offshore.

TABLE 6.-Major fields: Ventura basin

[Ranked by cumulative oil plus BOE to January 1, 1975]

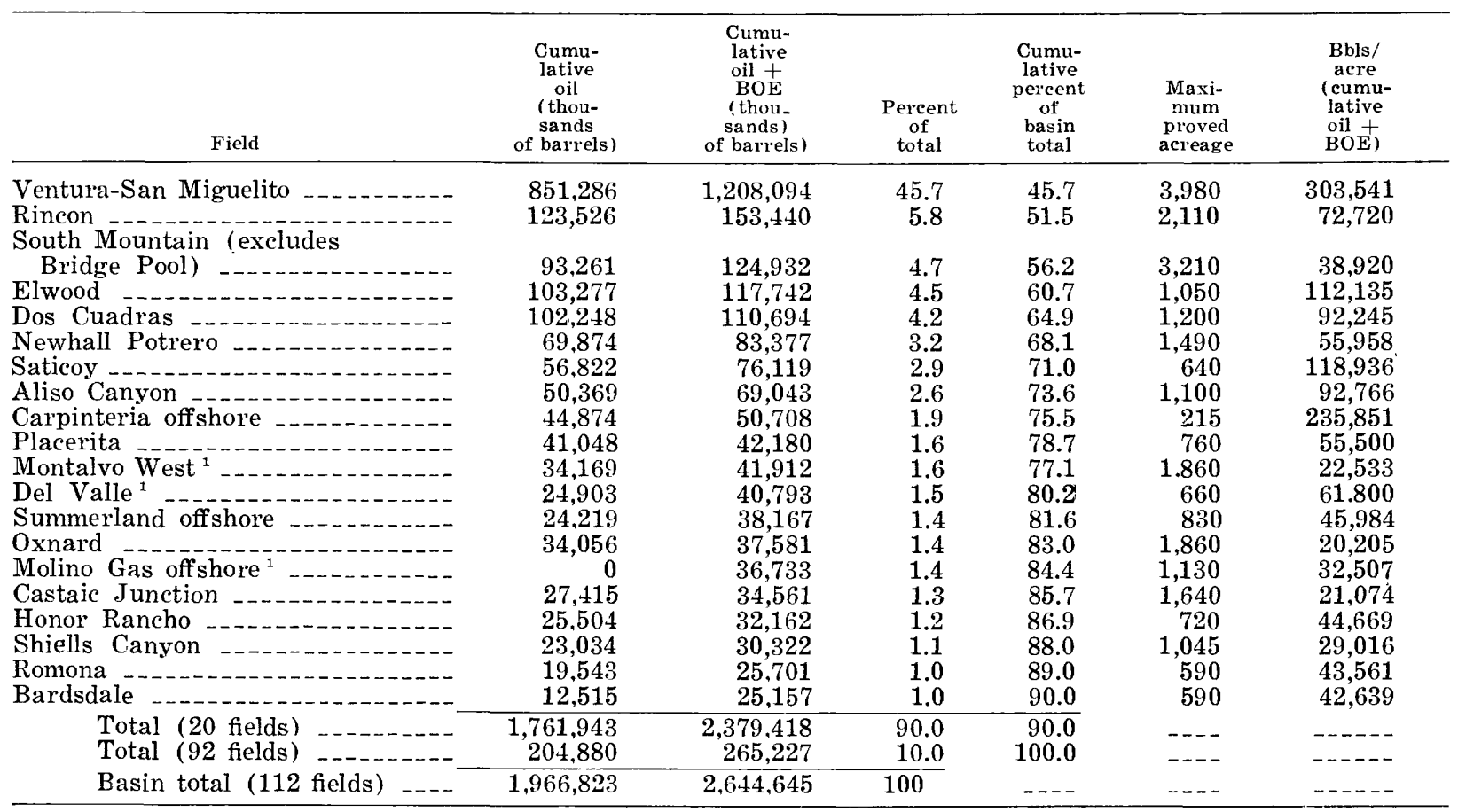

${ }^{1}$ Gas fields or fields with dry-gas zones. 
TABLE 7.-Major fields: Santa Maria basin

[Ranked by cumulative oil plus BOE to January 1, 1975]

\begin{tabular}{|c|c|c|c|c|c|c|}
\hline Field & $\begin{array}{l}\text { Cumu- } \\
\text { lative } \\
\text { oil } \\
\text { (thou- } \\
\text { sands of } \\
\text { barrels) }\end{array}$ & $\begin{array}{c}\text { Cumu- } \\
\text { lative } \\
\text { oil }+ \\
\text { BOE } \\
\text { (thou- } \\
\text { sands of } \\
\text { barrels) }\end{array}$ & $\begin{array}{c}\text { Percent } \\
\text { of } \\
\text { total }\end{array}$ & $\begin{array}{c}\text { Cumu- } \\
\text { lative } \\
\text { percent } \\
\text { of } \\
\text { total }\end{array}$ & $\begin{array}{c}\text { Maxi- } \\
\text { mum } \\
\text { proved } \\
\text { acreage }\end{array}$ & $\begin{array}{c}\text { Bbls/ } \\
\text { acre } \\
\text { (cumu- } \\
\text { lative } \\
\text { oil + } \\
\text { BOE) } \\
\end{array}$ \\
\hline Santa Maria Valley & 159,418 & 195,732 & 26.6 & 26.6 & 7.630 & 25,653 \\
\hline Orcutt & 148,796 & 172,714 & 23.5 & 50.1 & 4,730 & 36,515 \\
\hline Cat Canyon West & 136,576 & 152,841 & 20.8 & 70.9 & 2,980 & 51,289 \\
\hline Cat Canyon East & 37,535 & 38,115 & 5.2 & 87.9 & 3,470 & 10,984 \\
\hline Casmalia & 31,584 & 34,179 & 4.6 & 92.5 & 2,690 & 12,706 \\
\hline Total (7 fields) & 590,788 & 680,658 & 92.5 & 92.5 & -..- & $-\ldots-$ \\
\hline Others (13 fields) & 51,991 & 55,321 & 7.5 & 100 & $-\ldots$ & $\ldots-\ldots$ \\
\hline Basin total (20 fields) & 642,779 & 735,979 & 100 & $\ldots$ & $-\ldots$ & - - - - \\
\hline
\end{tabular}

TABLE 8.-Major fields: Cuyama basin

[Ranked by cumulative oil plus BOE to January 1, 1975]

\begin{tabular}{|c|c|c|c|c|c|c|}
\hline Field & $\begin{array}{l}\text { Cumu_ } \\
\text { dative } \\
\text { oil } \\
\text { (thou- } \\
\text { sands of } \\
\text { barrels) }\end{array}$ & $\begin{array}{c}\text { Cumu- } \\
\text { lative } \\
\text { oil }+ \\
\text { BOE } \\
\text { rthou- } \\
\text { sands of } \\
\text { barrels) }\end{array}$ & $\begin{array}{c}\text { Percent } \\
\text { of } \\
\text { total }\end{array}$ & $\begin{array}{c}\text { Cumu- } \\
\text { lative } \\
\text { of } \\
\text { basin } \\
\text { total }\end{array}$ & $\begin{array}{l}\text { Maxi- } \\
\text { mum } \\
\text { proved } \\
\text { acreage }\end{array}$ & $\begin{array}{c}\text { Bbs/ } \\
\text { acre } \\
\text { (cumu- } \\
\text { lative } \\
\text { oil + } \\
\text { BOE }\end{array}$ \\
\hline $\begin{array}{l}\text { Cuyama South } \\
\text { Russell Ranch }\end{array}$ & $\begin{array}{r}208,536 \\
64,887 \\
\end{array}$ & $\begin{array}{r}243,273 \\
71,977 \\
\end{array}$ & $\begin{array}{l}76.4 \\
22.6\end{array}$ & $\begin{array}{l}76.4 \\
99.0\end{array}$ & $\begin{array}{l}2,560 \\
1,550\end{array}$ & $\begin{array}{l}95,029 \\
46,437\end{array}$ \\
\hline $\begin{array}{l}\text { Total ( } 2 \text { fields) } \\
\text { Others }(3 \text { fields) }\end{array}$ & $\begin{array}{r}273,423 \\
2,868\end{array}$ & $\begin{array}{r}315,250 \\
3,183\end{array}$ & $\begin{array}{r}99.0 \\
1.0\end{array}$ & $\begin{array}{r}99.0 \\
100.0\end{array}$ & - & ---- \\
\hline
\end{tabular}

TABLE 9.-Major fields: Salinas and central coastal

[Ranked by cumulative oil plus BOE to January 1, 1975]

\begin{tabular}{|c|c|c|c|c|c|c|}
\hline Field & $\begin{array}{l}\text { Cumu_ } \\
\text { lative } \\
\text { oil } \\
\text { (thou- } \\
\text { sands of } \\
\text { barrels) }\end{array}$ & $\begin{array}{l}\text { Cumu- } \\
\text { lative } \\
\text { oil + } \\
\text { BoE } \\
\text { (thou- } \\
\text { sands of } \\
\text { barrels) }\end{array}$ & $\begin{array}{c}\text { Percent } \\
\text { of } \\
\text { total }\end{array}$ & $\begin{array}{c}\text { Cumu- } \\
\text { lative } \\
\text { of } \\
\text { basin } \\
\text { total }\end{array}$ & $\begin{array}{c}\text { Maxi- } \\
\text { mum } \\
\text { proved } \\
\text { acreage }\end{array}$ & $\begin{array}{c}\text { Bbls/ } \\
\text { acre } \\
\text { (cumu- } \\
\text { lative } \\
\text { oil }+ \\
\text { BOE) }\end{array}$ \\
\hline San Ardo & 274,181 & 286,032 & 96.5 & 96.5 & 4.490 & 63,704 \\
\hline Others (14 fields) & 4,572 & 5.936 & 3.5 & 100 & -..- & $-\ldots$ \\
\hline Total & 278,753 & 291,968 & 100 & $\ldots$ & - & $\ldots$ \\
\hline
\end{tabular}


TABLE 10.-Organic geochemistry of dart samples from the southern California borderland and Miocene outcrop samples from the southwestern Santa Ynez Mountains

[Analyses by U.S. Geological Survey Organic Geochemistry Laboratory, Lakewood, Colo.]

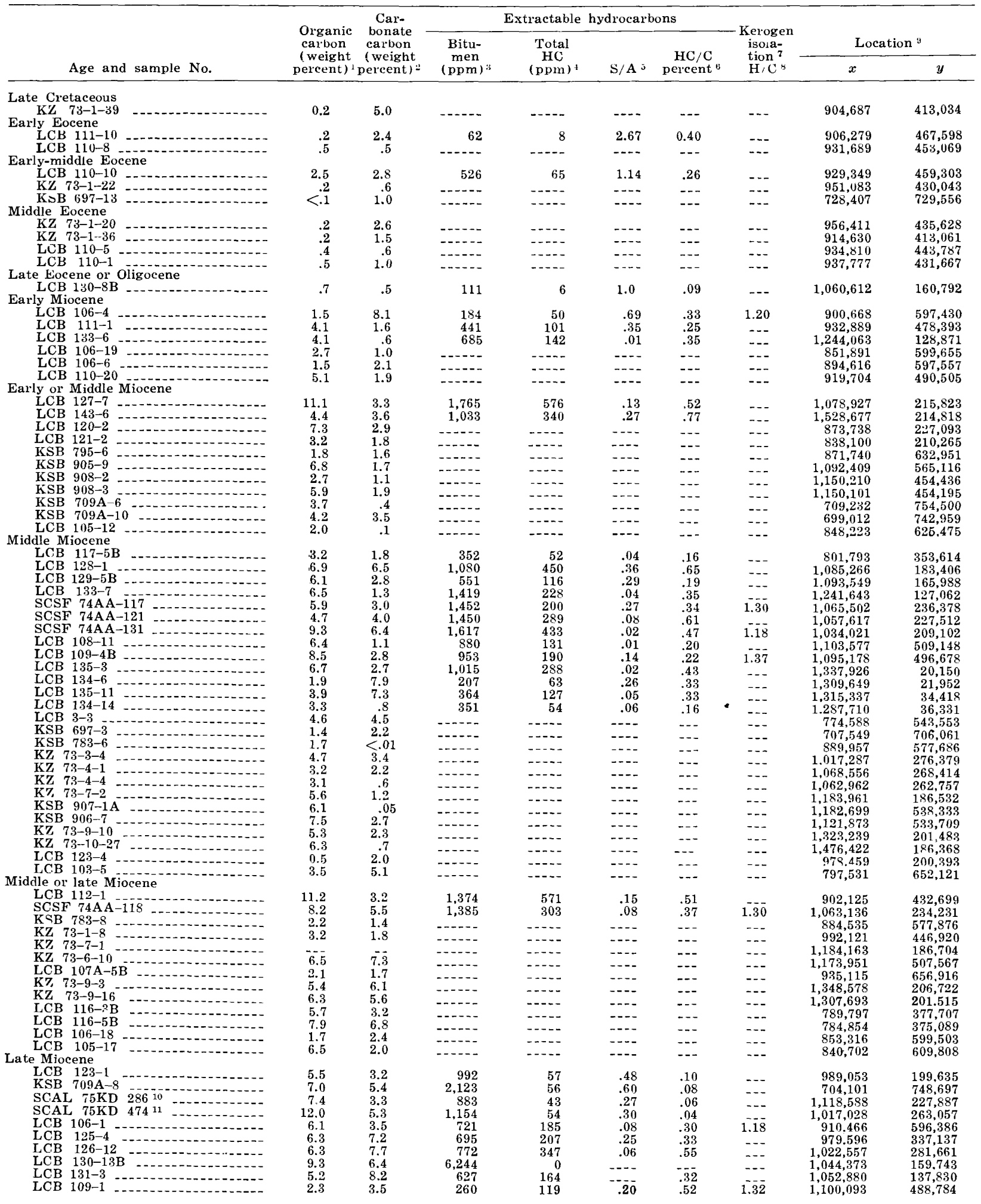

See footnotes at end of table. 
TABLE 10.-Organic geochemistry of dart samples from the southern California borderland and Miocene outerop samples from the southwestern Santa Ynez Mountains-Continued

\begin{tabular}{|c|c|c|c|c|c|c|c|c|c|}
\hline \multirow[b]{3}{*}{ Age and sample No. } & \multirow{3}{*}{$\begin{array}{c}\text { Organic } \\
\text { carbon } \\
\text { (weight } \\
\text { percent) }\end{array}$} & \multirow{3}{*}{$\begin{array}{l}\text { Car- } \\
\text { bonate } \\
\text { carbon } \\
\text { (weight } \\
\text { percent) }\end{array}$} & \multicolumn{4}{|c|}{ Extractable hydrocarbons } & \multirow{3}{*}{$\begin{array}{c}\text { Kerogen } \\
\text { isola- } \\
\text { tion } \\
\mathrm{H} / \mathrm{C}\end{array}$} & \multirow{2}{*}{\multicolumn{2}{|c|}{ Location ${ }^{\mathfrak{a}}$}} \\
\hline & & & \multirow{2}{*}{$\begin{array}{c}\text { Bitu- } \\
\text { men } \\
(\mathrm{ppm})^{*}\end{array}$} & \multirow{2}{*}{$\underset{\text { Total }}{\text { HC }}$} & \multirow[b]{2}{*}{$\mathrm{S} / \mathbf{A}^{5}$} & \multirow{2}{*}{$\underset{\text { percent }}{\mathrm{HC} / \mathrm{C}}$} & & & \\
\hline & & & & & & & & $x$ & $\boldsymbol{y}$ \\
\hline \multicolumn{10}{|l|}{ Late Miocene-Continued } \\
\hline SCSF 74AA 128 & 5.9 & 5.8 & 724 & 173 & .09 & .29 & 1.30 & $1,042,031$ & 213,417 \\
\hline KSB $697-1$ & 5.5 & 3.5 & $\ldots . .-2$ & $\ldots-$ & $-\ldots$ & $-\ldots$ & $\ldots$ & 707,128 & 705,717 \\
\hline KZ $73-1-1$ & 10.0 & 5.4 & $--\ldots$ & $\ldots$ & $-\ldots$ & -- & $\ldots$ & 996,675 & 459,800 \\
\hline KZ $73-4-3 \quad \ldots$ & 6.3 & 7.0 &..---- & $\ldots$. & $\ldots$ & -- & -- & $1,063,320$ & 262,807 \\
\hline KZ $73-7-5 \quad \ldots$ & 5.6 & 7.6 & ..... & $-\ldots$ & -..- & $\ldots$ & $\ldots$ & $1,173,951$ & 180,596 \\
\hline KZ $73-14-3 \quad \ldots \ldots$ & 7.5 & 4.6 & ---- & $\ldots$ & $\ldots$ & -- & -- & $1,285,010$ & 335,814 \\
\hline $\mathrm{KZ}, 73-14-14 \quad \ldots \ldots$ & 9.4 & 4.4 & $\ldots \ldots$ & $\cdots$ & --- & $\ldots$ & -- & $1,254,088$ & 324,027 \\
\hline LCB 141-5 & 6.7 & 5.7 & ...... & -...- & $-\ldots$ & $\ldots$ & $\ldots$ & $1,484,555$ & 161,989 \\
\hline KSB $709 A-22$ & 5.1 & .8 & 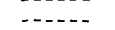 & $\ldots$ & -- & $-\ldots$ & $\ldots$ & 677.432 & 713,505 \\
\hline LCB 105-21 & 6.2 & 4.6 & $\ldots-.-1$ & $\ldots$. & $-\ldots$ & -- & -- & 845,384 & 600,414 \\
\hline \multicolumn{10}{|l|}{ Late Miocene or early Pliocene } \\
\hline $\mathrm{KZ} 73-2-40$ & 6.6 & 7.5 & $\ldots \ldots$ & $-\ldots-$ & $\ldots$ & $\ldots$ & $\ldots$ & 973.801 & 350,548 \\
\hline KZ 73-3-44 & 4.6 & 7.4 & ...... & ..... & ... & -.. & $\ldots$ & 963.601 & 344,629 \\
\hline KZ $73-9-28$ & 6.5 & 4.7 & 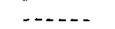 & $\ldots$. & $\ldots$ & $\ldots$ & $\ldots$ & $1,271,705$ & 190,728 \\
\hline \multirow{2}{*}{\multicolumn{10}{|c|}{$\begin{array}{l}\text { Holocene } \\
\text { SCAL } \quad 75 \mathrm{KD} \quad 41610\end{array}$}} \\
\hline & 1.0 & 4.3 & 229 & 58 & 2.00 & .58 & $-\ldots$ & $1,122,207$ & 92,169 \\
\hline \\
\hline Gav $10-9$ & 3.1 & 5.1 & 1,854 & 40,000 & $\begin{aligned}<.01 \\
1.15\end{aligned}$ & $\begin{array}{r}43.5 \\
1.5\end{array}$ & -- & $-1-2-1$ & n-n \\
\hline Gav $19-6 \mathrm{~A}$ & 6.4 & 1.3 & 5,214 & 1,128 & .15 & 1.76 & -- & $-1-2-1$ & $--n-1$ \\
\hline Aug $6 \mathrm{C}-10 \mathrm{~B}$ & 1.9 & 10.6 & 1,375 & 647 & .56 & 3.41 & -- & 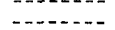 & - - - - \\
\hline Bix $7-2 \mathrm{~A}$ & 6.5 & $<.1$ & 9,982 & 1,278 & .1 & 2.0 & -- & $-n-1-1$ & 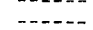 \\
\hline Wood 9-1 & 1.0 & $<.1$ & 1,018 & 159 & .22 & 1.59 & -- & $-\ldots-n$ & ----- \\
\hline
\end{tabular}

1 Acid-insoluble carbon by combustion.

Total carbon minus acid-insoluble carbon

"Total chloroform-extractable organic matter.

4 Sum of organic extract eluted from silica-gel with (a) heptane and (b) benzene.

5 Ratio of saturated hydrocarbons (heptane eluate) to aromatic hyd cocarbons (benzene eluate).

" Ratio of total hydrocarbon to organic carbon in percent.

N.

- Nonextractable organic natter isolated by $\mathrm{HC}$

${ }^{9}$ Lambert coordinates, California zone 6 .

"Samples frozen upon collection and hept frozen until analyzed.

11 Outcrop samples are from the Monterey Formation in the southwest Santa Ynez Moontains between Point Conception and Gaviota.

Variable lithnlogies as follows: Wood-3-1, calcareous: shale: Gav-10-9, dolomite calcareous shale; Gav-19-6A, cristobalitic shale: Aug-

$6 \mathrm{C}-10 \mathrm{~B}$, phosphatic dolomite; Bix-7-2A, quartz porcelanite; Wood-9-1, quartz chert. 
TABLE 11.-Organic geochemistry of Eocene outerop samples, San Nicolas Island [Analyses by Continental Oil Co.]

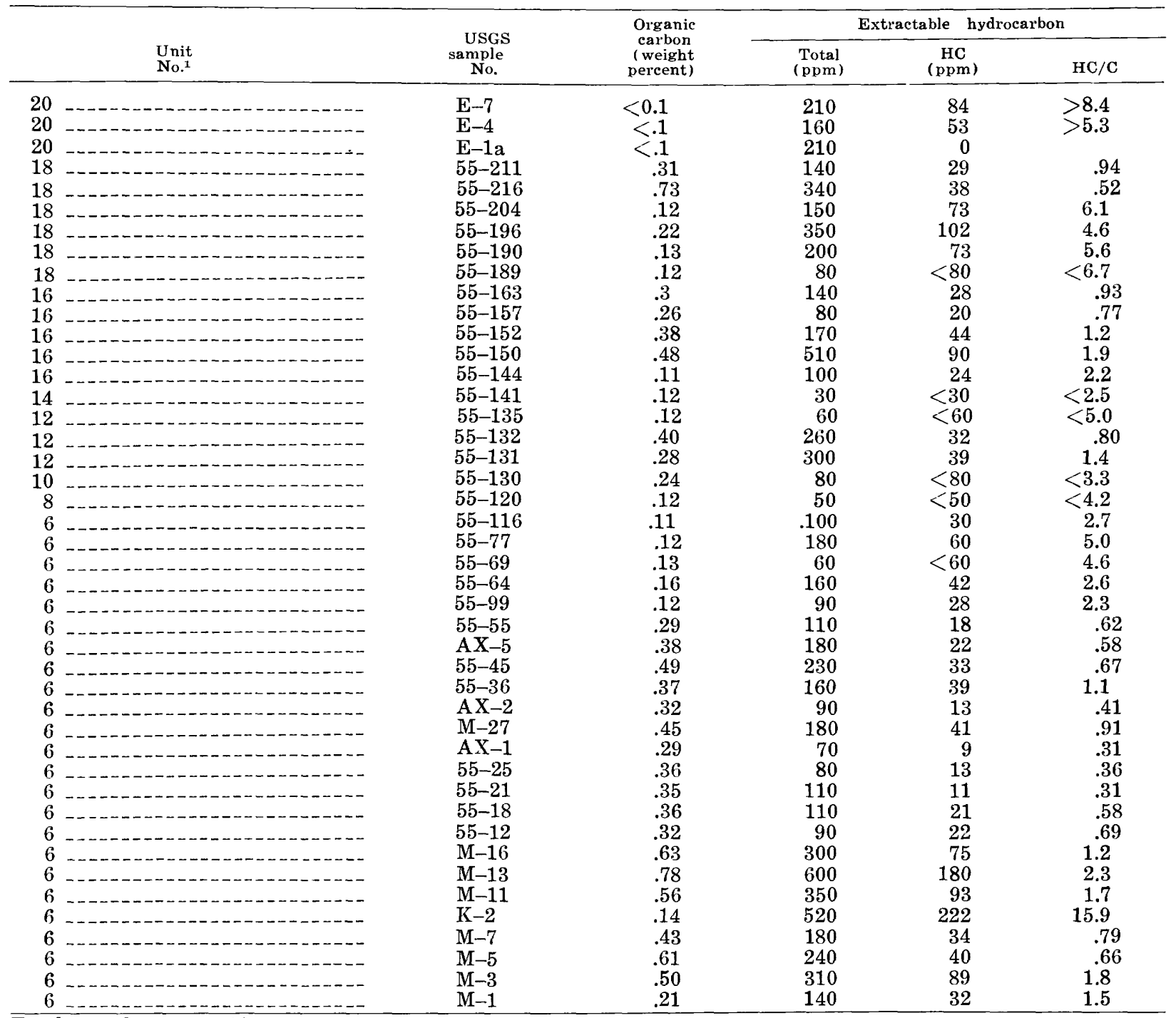

Total samples _.....44

Mean value, organic content wt. percent

$-0.30$

Standard deviation _.... 0.18

${ }^{1}$ Unit number shown in Vedder and Norris $(1963, \mathrm{pl} .5)$. 
